\title{
International Research into Chlorofluorocarbon (CFC) Alternatives
}

\author{
T. J. Marseille \\ D. L. Shankle \\ A. G. Thurman
}

May 1992

Prepared for the U.S. Department of Energy International Research Monitoring Program under Contract DE-AC06-76RLO 1830

Pacific Northwest Laboratory Operated for the U.S. Department of Energy by Battelle Memorial Institute 


\title{
DISCLAIMER
}

This report was prepared as an account of work sponsored by an agency of the United States Government. Neither the United States Gov'ernment nor any agency thereof, nor Battelle Memorial Institute, nor any of their employees, makes any warranty, expressed or implied, or assumes any legal liability or responsibility for the accuracy, completeness, or usefulness of any information, apparatus, product, or process disclosed, or represents that its use would not infringe privately owned rights. Reference herein to any specific commercial product, process, or service by trade name, trademark, manufacturer, or otherwise does not necessarily constitute or imply its endorsement, recommendation, or favoring by the United States Government or any agency thereof, or Battelle Memorial Institute. The views and opinions of authors expressed herein do not necessarily state or reflect those of the United States Government or any agency thereof.

\author{
PACIFIC NORTHWEST LABORATORY \\ operated by \\ BATTELLE MEMORIAL INSTITUTE \\ for the \\ UNITED STATES DEPARTMENT OF ENERGY \\ under Contract DE-ACO6-76RLO 1830
}

Printed in the United States of America

Available to DOE and DOE contractors from the

Office of Scientific and Technical Information, P.O. Box 62, Oak Ridge, IN 37831;

prices available from (615) 576-8401. FTS 626-8401.

Available to the public from the National Technical Information Service,

U.S. Department of Commerce, 5285 Port Royal Rd., Springfield, VA 22161. 
PNL- -8086

DE92 014241

INTERNATIONAL RESEARCH INTO

CHLOROFLUOROCARBON (CFC) ALTERNATIVES

T. J. Marseille

D. L. Shankle

A. G. Thurman

May 1992

Prepared for

the U.S. Department of Energy

International Research Monitoring Program

under Contract DE-ACO6-76RLO 1830

Pacific Northwest Laboratory

Richland, Washington 99352 


\section{EXECUTIVE SUMMARY}

Because of an international awareness of the potentially destructive impact that chloroflourocarbons (CFCS) and other halocarbons have on stratospheric ozone, industrial nations have agreed to a timetable for the phaseout of CFCs, halons, and related components. This timetable, included as part of the international treaty called the Montreal Protocol (Marseille and Baechler 1990), has acted as a driving force in instigating worldwide research activities into CFC alternatives. To explore the scope and direction of these activities, Pacific Northwest Laboratory conducted a survey for the U.S. Department of Energy on international research into alternatives for CFCs. (a)

Selected researchers from 21 countries were queried through questionnaires about their current and planned research activities. The results of the survey show that the majority of research being conducted by the respondents is devoted to investigating the hydrogenated fluorocarbon HFC-134a as a replacement for CFC-12 in refrigeration applications. The main issue with this alternative is identifying compatible lubricants that do not reduce its effectiveness.

Although researchers in different countries are often investigating similar alternatives, they appear to be at different stages of research. For example, some researchers are at more advanced development stages, conducting laboratory and field tests of alternatives in end-use applications, while others are still conducting more basic research, such as analyzing the thermal and chemical properties of a specific alternative. Improved international communication could help bridge this discontinuity in research progress. Moreover, the survey results indicate there is a strong interest in learning about the status and results of the research efforts of other researchers.

(a) This report was prepared through the International Research Monitoring Program (IRM), which was established in 1985 to liunitor and evaluate the current status and future directions of international research and development activities of interest to the U.S. Department of Energy's Conservation and Renewable Energy Program (DOE/CE). The IRM Program is managed by the DOE/CE Office of Technical Affairs with technical assistance from Pacific Northwest Laborator:." 


\section{CONTENTS}

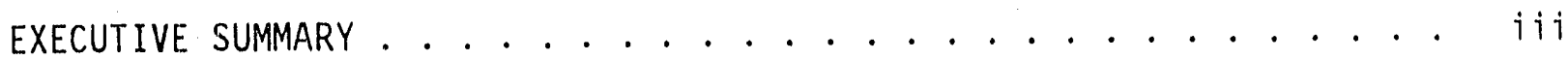

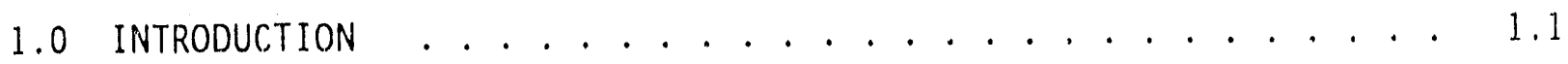

2.0 METHODOLOGY . . . . . . . . . . . . . . . . . . . . . 2.1

3.0 RESULTS OF THE SURVEY . . . . . . . . . . . . . . . . . . . . 3.1

3.1 LENGTH OF RESEARCH . . . . . . . . . . . . . . . . 3.1

3.2 IDENTIFICATION OF ALTERNATIVES . . . . . . . . . . . . 3.1

3.3 PURPOSE OF THE RESEARCH ............... . . . 3.4

3.3.1 HFC-134a ................. 3.5

3.3 .2 HCFC-22 . . . . . . . . . . . . . . . 3.5

3.3.3 Other Compounds ............... . . 3.6

3.4 ISSUES . . . . . . . . . . . . . . . . . . . 3.11

3.4.1 HFC-134a .................. 3.12

3.4 .2 HCFC -22 . . . . . . . . . . . . . . . 3.12

3.5 RESEARCH PLANS ... . . . . . . . . . . . . 3.13

3.6 RESEARCH THAT SHOULO BE PURSUED . . . . . . . . . . . . . . 3.14

3.7 FUNDING . . . . . . . . . . . . . . . . . . 3.15

3.7.1 Funding Levels .............. . 3.16

3.7.2 Funding Sources .............. . 3.16

3.8 RESEARCH DISSEMINATION . . . . . . . . . . . . . . 3.16

4.0 CONCLUSIONS AND RECOMMENDATIONS . . . . . . . . . . . . . . . . . 4.1

4.1 CONCLUSIONS ........................... 4.1

4.2 RECOMMENDATIONS . . . . . . . . . . . . . . . . . . 4.2

5.0 REFERENCES .......................... 5.1 
APPENDIX A - QUESTIONNAIRE . . . . . . . . . . . . . . A.1
APPENDIX B - COVER LETTER . . . . . . . . . . . . . . . B. 1
APPENDIX C - QUESTIONNAIRE DISTRIBUTION LIST . . . . . . . . . $\quad$. . 1 


\section{TABLES}

1.1 Environmental Effects of CFCs and Possible Alternatives . . . 1.3

1.2 Phaseout Schedules Adopted at the June 1990 United Nations Environmental Program (UNEP) Meeting in London . . . . . . 1.5

2.1 Number of Researchers Contacted and the Number that

Responded by Country................ 2.2

3.1 Length of Time that Respondents Have Been Conducting Research . . 3.1

3.2 Specific Alternative Compounds that Respondents Believe Offer the Most Potential for Alleviating the CFC Problem . . . . . . 3.2

3.3 Specific Alternative Compounds that Respondents in Each Country Believe Offer the Most Potential for Alleviating the CFC Problem 3.3

3.4 Purpose of the Research . . . . . . . . . . . . . . . . 3.4

3.5 Specified Problems/Issues Identified with the Research . . . . . 3.11

3.6 Other Groups/Organizations Conducting CFC Research . . . . . . 3.15

3.7 Exchange Rates, January 2, 1990 . . . . . . . . . . . . . 3.17

3.8 Research Budgets by Country . . . . . . . . . . . . . 3.18

3.9 Funding Sources .................... . 3.18 


\subsection{INTRODUCTION}

Chlorofluorocarbons (CFCS) are chemically stable members of the halocarbon family that are derived from common hydrocarbons such as methane, ethane, and propane. The halocarbons also include hydrogenated chloroflourocarbons (HCFCS), hydrogenated fluorocarbons (HFCS), brominated hydrocarbons (or halons), as well as miscellaneous chlorinated hydrocarbons such as carbon tetrachloride and methyl chloroform. Of al1 the halocarbons, CFCs are of greatest concern with regard to stratospheric ozone damage.

About $30 \%$ of CFCs produced worldwide are used as the refrigerant working fluids in vapor-compression cycle air conditioning and refrigeration systems and as blowing agents $(28 \%)$ in the production of insulating foams and packaging. They are also used for aerosols (19\%), as solvents for electronics cleaning (19\%), and for other miscellaneous uses (4\%). Primary industries that use CFCs include commercial and residential construction, food processing, transportation, electronics, and plastics. Altogether, worldwide annual production of CFCs reached approximately 2 billion pounds in 1986 in noncentrally planned economies (Moore 1989).

CFCs have life expectancies on the order of 100 years. It is theorized that over time individual CFC molecules that have been released on the earth's surface diffuse into the stratosphere where they will break down under ultraviolet (UV) bombardment from the sun (Rowland and Molina 1975). Once broken down, the halogen chlorine, found in a11 C.FCs, disrupts normal stratospheric chemistry, causing ozone destruction. It has been estimated that every free atom of chlorine can participate in the destruction of 100,000 ozone molecules (Rowland and Molina 1975). This destruction is environmentally significant because the "ozone-layer" in the stratosphere normally acts as a protective shield to the earth, effectively blocking the sun's harmful UV rays from reaching the surface. The U.S. Environmental Protection Agency (EPA) has predicted that every $1 \%$ decrease in ozone will result in a $1 \%$ to $2 \%$ increase in the incidence of melanoma skin cancer (EPA 1987). Other expected effects of ozone depletion include crop damage, increased incidence of cataracts, 
increased formation of tropospherical ozone (smog), and increased degradation of manmade materials such as polymers (EPA 1987). The term ozone depletion potential (ODP) has been developed to provide a relative measure of the detrimental effect that different chemicals have on the ozone layer.

The second threat caused by the release of CFCs into the atmosphere is globar warming, also known as the greenhouse effect. Concentrations of various gases found in the atmosphere, known collectively as greenhouse gases, are increasing because of human activities. Among these gases are CFCS and carbon dioxide $\left(\mathrm{CO}_{2}\right)$. Because of these larger concentrations, a larger portion of the long-wave radiation emitted from the earth's surface that previously escaped into space is absorbed by these gases, producing additional heat that warms the atmosphere. The term global warming potential (GWP) have been developed as a relative measure of the potential of various greenhouse gases to absorb long-wave radiation. The GWP of CFCs is as much as 10,000 times as large as that of $\mathrm{CO}_{2}$, which is by far the most prevalent greenhouse gas. Thus, though much smaller concentrations of CFCs than $\mathrm{CO}_{2}$ are present in the atmosphere, it is estimated that CFCs contribute approximately $10 \%$ to $15 \%$ to the greenhouse effect (WMO 1985). The ODPs, GWPs, and atmospheric life expectancies of each of the major halocarbons are summarized in Table 1.1.

In CFCs, al1 of the hydrogen atoms surrounding the carbon atoms in the original hydrocarbons are replaced by either fluorine or chlorine, which are two halogen elements. The HCFCs are similar to CFCs except that some of the original hydrogen atoms remain. These compounds generally contain less chlorine and break down sooner in the atmosphere than CFCs. Thus, HCFCS have lower ODPs, which means that they have less of an impact on the ozone layer. Their shorter atmospheric 1 ifetimes also result in lower GWPs, which reduces global warming as well. In addition, many HCFCs have thermodynamic and physical properties similar to those of CFCS. These lower ODP and GWP CFCS, at least in the near term, appear to be attractive potential candidates for replacing CFCs in many applications.

The HFCs are fluorine compounds that are similar to HCFCs and CFCs except they contain no chlorine. Consequently, they have ODPs of zero. They a) so have shorter atmospheric lifetimes than CFCs and, thus, lower GWPs. 
TABLE 1.1. Environmental Effects of CFCs and Possible Alternatives

\begin{tabular}{|c|c|c|c|c|c|}
\hline $\begin{array}{c}\text { Fluid Number } \\
\text { Name }\end{array}$ & Formula & $\underline{O D P^{(a)}}$ & $\begin{array}{r}\text { GW } \\
100 \text { year. } \\
\end{array}$ & $\begin{array}{l}\text { (b) } \\
500 \text { year }\end{array}$ & $\begin{array}{l}\text { Atmospheric } \\
\text { Life(c) (year) }\end{array}$ \\
\hline HFC -23 & $\mathrm{CHF}_{3}$ & 0 & & $12,000^{(\mathrm{d})}$ & $310^{(d)}$ \\
\hline $\mathrm{HFC}-32$ & $\mathrm{CH}_{3} \mathrm{~F}_{2}$ & 0 & & $220^{(d)}$ & $6^{\text {(d) }}$ \\
\hline HFC-125 & $\mathrm{CF}_{3}^{2} \mathrm{CHF}_{2}$ & 0 & 2,500 & 860 & 28 \\
\hline$H F C-143 a$ & $\mathrm{CF}_{3} \mathrm{CH}_{3}{ }^{2}$ & 0 & 2,900 & 1,000 & 41 \\
\hline Propane & $\mathrm{CH}_{3} \mathrm{CH}_{2}^{3} \mathrm{CH}_{3}$ & 0 & $3^{(\mathrm{e})}$ & $3^{(\mathrm{e})}$ & $<1$ \\
\hline HCFC-22 & $\mathrm{CHCTF}_{2}$ & 0.05 & 1,500 & 510 & 15 \\
\hline Ammonia & $\mathrm{NH}_{3}$ & 0 & & & $<1$ \\
\hline$H F C-134 a$ & $\mathrm{CF}_{3} \mathrm{CH}_{2} \mathrm{~F}$ & 0 & 1,200 & 420 & 16 \\
\hline$H F C-152 a$ & $\mathrm{CHF}_{2} \mathrm{CH}_{3}$ & 0 & 140 & 47 & 2 \\
\hline HFC-134 & $\mathrm{CHF}_{2} \mathrm{CHF}_{2}$ & 0 & & & $12^{(d)}$ \\
\hline HFC-227ea & $\mathrm{CF}_{3} \mathrm{CHFCF}_{3}$ & 0 & & & \\
\hline HCFC-124 & $\mathrm{CHCTFCF}_{3}$ & 0.02 & 430 & 150 & 7 \\
\hline Isobutane & $\mathrm{CH}\left(\mathrm{CH}_{3}\right)_{3}^{3}$ & 0 & $3^{(\mathrm{e})}$ & $3^{(\mathrm{e})}$ & $<1$ \\
\hline HCFC-142b & $\mathrm{CClF}_{2} \mathrm{CH}_{3}^{3}$ & 0.06 & 1,600 & 540 & 19 \\
\hline$n$-butane & $\mathrm{CH}_{3}\left(\mathrm{CH}_{2}\right)_{2} \mathrm{CH}_{3}$ & 0 & $3^{(\mathrm{e})}$ & $3^{(e)}$ & $<1$ \\
\hline$E-134$ & $\mathrm{CHF}_{2} \mathrm{OCHF}_{2}$ & 0 & & & $<12$ \\
\hline HCC -160 & $\mathrm{CH}_{2}{ }^{2} \mathrm{C} 7 \mathrm{CH}_{3}{ }^{2}$ & 0.02 & 3 & 3 & $<1$ \\
\hline HCFC -123 & $\mathrm{CHC}_{2}, \mathrm{CF}_{3}$ & 0.02 & 85 & 29 & 2 \\
\hline$E-245$ & $\mathrm{CF}_{3} \mathrm{CH}_{2} \mathrm{OCHF}_{2}$ & 0 & & & \\
\hline HCFC-141b & $\mathrm{CC}_{2}^{3}{ }_{2} \mathrm{FCH}_{3}$ & 0.10 & 440 & 150 & 8 \\
\hline Carbon Dioxide & $\mathrm{CO}_{2}{ }^{2}$ & 0 & 1 & 1 & 120 \\
\hline CFC -13 & $\mathrm{CClF}_{3}$ & & & & 400 \\
\hline CFC-115 & $\mathrm{CClF}_{2}^{3} \mathrm{CF}_{3}$ & 0.35 & 6,900 & 7,400 & 400 \\
\hline CFC -12 & $\mathrm{CCl}_{2} \mathrm{~F}_{2}$ & 0.9 & 7,300 & 4,500 & 130 \\
\hline CFC -114 & $\mathrm{CClF}_{2} \mathrm{C} C \mathrm{ClF}$ & 0.7 & 6,900 & 5,500 & 200 \\
\hline CFC-11 & $\mathrm{CCl}_{3} \mathrm{~F}$ & 1 & 3,500 & 1,500 & 60 \\
\hline CFC- 113 & $\mathrm{CC} \mathrm{F}_{2} \mathrm{CCl}_{2} \mathrm{~F}$ & 0.8 & 4,200 & 2,100 & 90 \\
\hline
\end{tabular}

\footnotetext{
(a) ODP values are relative to R11 and are averages of the 2-dimensional model results presented in WMO Report No. 20, Vol. 11 (1989).

(b) Global warming potentials are from the IPCC Scientific Assessment (1990), except as noted; values are relative to $\mathrm{CO}_{2}$ and are given for 100 and 500 year integration time horizons.

(c) Atmospheric lifetimes are from WMO Report No. 20, Vol II (1989), except as noted.

(d) Estimates based on limited data, GWP is steady-state value (McFarland, personal communication).

(e) GWP of the hydrocarbons is due almost entirely to GWP of the $\mathrm{CO}_{2}$ resulting from decomposition.
} 
Therefore, the use of these substances in applications that currently employ CFCs is environmentally highly desirable.

Halons differ from CFCs in that they include bromine, the heaviest halogen element. Bromine has a higher potential for ozone damage that chlorine; thus, halons are usually included in eivironmental discussions about CFCs for completeness. Halons are used primarily as a fire-extinguishing agent in total flooding systems for critical civilian electronics installations and military applications. Researchers queried for this study were exclusively looking at alternatives for CFCs; therefore, halons will not be discussed further in this report.

In response to the recognized threat.CFCs pose to the ozone layer, over 60 nations, including major world economies that produce and use CFCS, participated in drafting an international treaty known as the Montreal protocol on Substances that Deplete the Ozone Layer. The treaty originally committed signatory nations to reduce the production of CFCs, halon gases, carbon tetrachloride, and methyl chloroform by $50 \%$ by the year 1998 .

More recent scientific evidence has indicated an even higher ozonedepleting potential for chlorine and bromine compounds than originally suspected, prompting further international research. A March 1989 meeting of the European Economic Community (EEC) called for a complete CFC phaseout in production by 2000 and a complete phaseout in production of HCFCs by 2005 . The signatory parties to the Montreal Protocol met in Helsinki, Finland, in May 1989 and approved a declaration that stated a similar intent to phaseout consumption of CFCs by the year 2000 (assuming acceptable alternatives are available) and to refrain from using other halons except for essential applications. In London in June 1990 the Second Meeting of the Parties to the Montreal Protocol on Substances that Deplete the Ozone Layer resulted in the adoption of these more stringent amendments, summarized in Table 1.2. In addition, it was resolved at the London meeting that guidelines would be applied to facilitate the use of HCFCS in place of CFCs where necessary. These guidelines would include the regular review of alternative products to HCFCs, with a view to replace HCFCs no later than 2040 and, if possible, no later than 2020. 
TABLE 1.2. Phaseout Schedules Adopted at the June 1990 United Nations Environmental Program (UNE.P) Meeting in London

Compound

CFCs

Halons

Carbon tetrachloride

Methy 1 chloroform
Goal

Production phaseout by year 2000 if environmentally acceptable alternatives are available

Phaseout by 2000 , unless satisfactory substitutes are identified for essential applications

Production phaseout by year 2000 if environmentally acceptable alternatives are available

Production phaseout by year 2005.

Clearly, the progress toward the development of alternative compounds will have a significant impact on the effectiveness of the treaty. To assess this progress, Pacific Northwest Laboratory (PNL) ${ }^{(a)}$ conducted a study for the U.S. Department of Energy (DOE) International Research Monitoring Program to obtain a global perspective on and document foreign research activities into CFC alternative chemical compounds.

Section 2.0 of the report describes the methodology used to survey scientists. The results of the survey are then described in Section 3.0, with conclusions presented in Section 4.0. A copy of the questionnaire is contained in Appendix A. Appendix B contains the cover letter, and Appendix $C$ coniains a list of who was sent the questionnaires.

(a) Pacific Northwest Laboratory is operated for the U.S. Department of Energy by Battelle Memorial Institute under Contract DE-ACD6-76RLO 1830 . 


\subsection{METHODOLOGY}

The goal of this study is to document international research activities being conducted to find replacements for CFCs. Although this information is widely available from conference proceedings and other published references, frequently the information is out-of-date because of the length of time from submittal to publication. Therefore, a mail questionnaire was developed to provide the most current information on international research activities and to gather more detailed information than normally provided in research article:.

The questionnaire asked researchers to provide information about their specific research projects ruyarding CFC replacements, the results of the research to-date, problems encountered and how these were overcome, current and projected funding levels for their research as well as their sources for funding, and potential research projects in the iear future. A copy of the questionnaire is, in Appendix A.

The list of international researchers was generated from a 1 iterature review of all recently published international research on CFC replacements. Some of the sources include the June 1991 issue of the International Energy Agency (IEA) Heat Pump Centre Newsletter, the proceedings from the 1990 International Conference on CFC and Halon Alternatives, and the 1990 U.S. National Cormittee for the International Institute of Refrigeration (USNC/IIR) Purdue Conference.

The questionnaire was sent to all international researchers that published within the last 5 years. In addition to the literature review, contacts were made with U.S. researchers and staff at DOE to identify other international researchers. Due to sensitivity issues, several countries who are known to be conducting research into CFC replacements (e.g., USSR) were not sent questionnaires; therefore, their current research is not included in the report.

The questionnaire and a cover letter (see Appendix B; explaining the purpose of the questionnaire were sent to 131 individuals in 21 countries. A list of those sent the questionnaire is contained in Appendix $C$. The 
questionnaire was sent during March 1991. As of June 1991, 81 questionnaires $(62 \%)$ were returned. A listing of the number of researchers who returned the questionnaire by country is provided in Table 2.1.

Although an attempt was made to identify all international researchers studying replacements to CFCs, unfortunately some will have been overlooked. The results of this study should be viewed as providing an overview of current international research activities on CFC replacements; not a complete documentation of all research efforts.

TABLE 2.1. Number of Researchers Contacted and the Number that Responded by Country

\begin{tabular}{lccc}
\multicolumn{1}{c}{ Country } & & $\begin{array}{c}\text { Number of } \\
\text { Contacts }\end{array}$ & $\begin{array}{c}\text { Number of } \\
\text { Respondents }\end{array}$ \\
\cline { 3 - 3 } Australia & 2 & 2 \\
Austria & 2 & 2 \\
Brazil & 5 & 3 \\
Canada & 17 & 6 \\
China & 3 & 1 \\
Denmark & 4 & 4 \\
France & 3 & 3 \\
Germany & 14 & 10 \\
India & 4 & 3 \\
Italy & 2 & 1 \\
Japan & 35 & 23 \\
Kenya & 1 & 1 \\
Korea & 1 & 1 \\
Mexico & 3 & 1 \\
New Zealand & 1 & 1 \\
Norway & 6 & 4 \\
Sweden & 5 & 3 \\
Switzerland & 3 & 2 \\
Taiwan & 1 & 1 \\
The Netherlands & 3 & 2 \\
United Kingdom & 15 &
\end{tabular}




\subsection{RESULTS OF THE SURVEY}

This section describes the results of the survey. Some of the answers provided on the questionnaire were difficult to decipher, primarily due to the language barrier. Also, some of the respondents offered little detail in their answers.

\subsection{LENGTH OF RESEARCH}

Most of the respondents indicated that they began research into CFC. related issues 3-5 years ago. Most also expected to continue research activities for 3 ur more years. These results indicate that the CFC issue is recognized is a serious international issue, and that identifying and then developing alternatives are requiring an intensive, ongoing research effort. Table 3.1 contains the respondents' answers to the questions about the length of time of their research.

\subsection{IDENTIFICATION OF ALTERNATIVES}

Although many CFC alternatives are being studied, various HCFCS, HFCS, and mixtures of the two are by far the most widely researched. The most prevalent alternatives being studied by the respondents were HFC-134a and, to a lesser extent, HCFC-22. Table 3.2 lists (by percent) what CFC alternatives were identified in the surveys as having a high potential for alleviating the

TABLE 3.1. Length of Time that Respondents Have Been Conducting Research (Percent of Respondents)

\begin{tabular}{lcc} 
More than 5 years & $\begin{array}{c}\text { How Long } \\
\text { Research Has } \\
\text { Been Conducted }\end{array}$ & $\begin{array}{c}\text { How Long } \\
\text { Research } \\
\text { Will Continue }\end{array}$ \\
\cline { 2 - 3 } $3-5$ years & $16 \%$ & $35 \%$ \\
$1-2$ years & $47 \%$ & $31 \%$ \\
Less than 1 year & $17 \%$ & $11 \%$ \\
Missing & $4 \%$ & $7 \%$ \\
& $16 \%$ & $16 \%$
\end{tabular}


IABLE 3.2. Specific Alternative Compounds that Respondents Believe Offer the Most Potential for Alleviating the CFC Problem

\begin{tabular}{cc} 
Alternative Compound & Respondents \\
\cline { 2 - 2 } HFC-134a & $36 \%$ \\
HCFC-22 & $9 \%$ \\
HFC-152a & $5 \%$ \\
Ammonia & $4 \%$ \\
Other & $20 \%$ \\
Missing & $26 \%$
\end{tabular}

CFC problem. Specifically, over one-third of the respondents reported the i.) ternative HFC-134a as having the most potential for alleviating the CFC

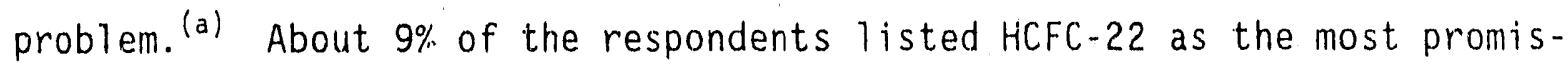
ing alternative, and a few of the respondents mentioned either HFC-152a or ammonia $\left(\mathrm{NH}_{3}\right)$.

Most of the respondents from Japan, Germany, and the United Kingciun are analyzing HFC-134a. However, a large number of Japanese and United Kingdom respondents did not identify the specific alternative(s) they were researching. Table 3.3 lists specific CFC alternatives respondents from individual countries chose as providing the most potential for alleviating the CFC problem. Only those countries with three or more responses are listed.

(a) Interestingly, though HCFCS were often cited by researchers as alternatives, these chemicals offer at best only a temporary solution because they still contain some chlorine. Because of this, their eventual production phaseout is also expected by 2020-2030. 
TABLE 3.3. Specific Alternative Compounds that Respondents in Each Country Believe Offer the Most Potential for Alleviating the CFC Problem

$\frac{\text { Country }}{\text { Japan }}$

Germany

United Kingdom

Canada

Denmark

Norway

Brazil

Ind ia

Sweden

\begin{tabular}{r} 
Perce \\
\hline 48 \\
9 \\
4 \\
4 \\
35 \\
\\
50 \\
20 \\
10 \\
10 \\
10
\end{tabular}

25

13

13

13

38

33

33

17

17

50

50

50

25

25

67

33

33

33

33

33

33

33
Alternative Compound

HFC - $134 \mathrm{a}$

HCFC-22

Aqueous Cleaning

HCFC -123

Missing

HFC-134a

HFC $-152 a$

R718

Hydrogen

Missing

HFC $-134 a$

HFC- $152 \mathrm{a}$

ISCEON $69 \mathrm{~S}$

Ammonia

Missing

HCFC \& HFC

HFC $-134 a$

HFC - $152 \mathrm{a}$

Missing

HFC-134a

Missing

HCFC-22

Ammonia

Missing

HFC-134a

Missing

Azeotrope

HCFC-22

HFC - $134 \mathrm{a}$

HFC - $134 \mathrm{a}$

NARMS

Ammonia 


\subsection{PURPOSE OF THE RESEARCH}

Most of the respondents indicated they are currently investigating the application of one or more CFC alternatives to vapor-compression cycle refrigeration/air-conditioning equipment. Of these respondents, about half are looking at HFC-134a. Over one-third of the respondents are conducting theoretical performance analyses of the vapor-compression cycle. Of these, almost half are studying $\mathrm{HFC}-134 \mathrm{a}$ and a smaller percentage are studying HCFC-22. About one-third of respondents reported analyzing thermodynamic properties of alternatives, and one-third are studying the compatibility of the varlous alternatives with materials used in air-conditioning and refriger ation equipment. Again HFC-134a is the dominant compound being analyzed for both purposes. Table 3.4 lists the different purposes of the research. Because of the high frequencies of HFC-134a and HCFC-22 on the surveys, additional information is presented here.

TABLE 3.4, Purpose of the Research

\begin{tabular}{lccc} 
Purpose & $\begin{array}{c}\text { Al1 } \\
\text { Respondents }\end{array}$ & $\begin{array}{c}\text { HFC-134a } \\
\text { Respondents }\end{array}$ & $\begin{array}{c}\text { HCFC-22 } \\
\text { Respondents }\end{array}$ \\
\cline { 1 - 3 } Test Applications & $57 \%$ & $69 \%$ & $57 \%$ \\
Refrigeration/Air-Conditioning & $64 \%$ & $86 \%$ & $86 \%$ \\
Insulation/Blowing Agent & $10 \%$ & $3 \%$ & $14 \%$ \\
Electronics Cleaner & $6 \%$ & $0 \%$ & $0 \%$ \\
Fire Extinguisher & $1 \%$ & $0 \%$ & $0 \%$ \\
Other Applications & $12 \%$ & $3 \%$ & $14 \%$ \\
& & & \\
Test Properties & $36 \%$ & $41 \%$ & $29 \%$ \\
Thermodynamic Properties & $32 \%$ & $38 \%$ & $43 \%$ \\
Vapor Compression Cycles & $38 \%$ & $45 \%$ & $57 \%$ \\
Materials Compatibility & $32 \%$ & $45 \%$ & $0 \%$ \\
Reactivity & $12 \%$ & $14 \%$ & $0 \%$ \\
Environmental Impact & $5 \%$ & $0 \%$ & $0 \%$ \\
Other Properties & $15 \%$ & $17 \%$ & 14
\end{tabular}




\section{3 .1 HFC-134a}

The compound HFC-134a was frequently cited as a replacement for CFC-12, which is currently used extensively in refrigeration, water chlliing, and car air-conditioning applications. Therefore, it was not surprising that of those investigating $\mathrm{HFC}-134 \mathrm{a}$, almost $90 \%$ are interested in refrigeration and airconditioning applications. Just under half of these respondents are involved in optimization studies of the vapor-compression cycle when using HFC-134a. About half of the researchers are also involved in examining materials compatibility issues, and half are involved in testing to establish thermodynamic and chemical properties of HFC-134a. Table 3.4 lists the purposes of the research into this specific compound.

The specific materials compatibility research issue cited most frequently by researchers was finding appropriate lubricants for HFC-134a vaporcompression cycle equipment. One respondent is also conducting compatibility tests with metals. Another respundent is reportedly developing a test apparatus to measure thermodyramic properties (presumably, also applicable to testing of other alternatives). However, because most researchers reported looking at applications and materials compatibility issues, the majority seem to have either concluded thermodynamic property testing or have access to thermodynamic data collected by others.

Other HFC-134a iesearch areas that were mentioned by at least two respondents also relate to vapor-compression refrigeration cycle applications, and include 1) testing the suitability of desiccants, 2) optimizing refrigeration compressor designs, and 3) conducting heat transfer tests to establish heat exchanger performance and transport properties. Finally, one respondent is looking at the feasibility of retrofitting CFC-12 systems for use with HFC-134a, and another is conducting long-term aging tests of vapor-compression cycle equipment that uses HFC-134a.

\section{3 .2 HCFC-22}

of those respondents who indicated HCFC-22 as the main compound they are studying, most are studying vapor-compression equipment applications. Perhaps because this compound is already widely used in residential and 
commercial applications the respondents seemed to be in relatively advanced stages of research. One respondent indicated that a CFC-12 system had been converted to HCFC-22 "at a reasonable cost," and one had conducted experimental tests of a HCFC $-22 / H C F C-142$ b binary mixtures in refrigerators, yielding results that are "very satisfactory." Other respondents are conducting thermodynamic calculations of ternary blends. Table 3.4 lists the purposes of the research into this specific compound.

\subsection{3 other Compounds}

A number of specific alternatives were mentioned by either one or very few respondents. Listed below are those alternatives, the country conducting the research, the purpose of the research, and any problems with the alternative.

Aqueous Cleaning. A respondent from Japan and one from Switzerland are looking at using an aqueous cleaning solution to replace CFC-113 as an electronics cleaner. Specifically, the Japanese respondent has

replaced CFC-dependent draining and drying technology with a dipping and drying device that used distilled water, and... [he is] investigating the use of spin drying and other existing technologies.... [The respondent is] studying the use of washing technology that uses water-based solvents instead of CFCs... [and is] developing substitutes for CFCs used for dilution purposes in surface treatment processes.

The Swiss respondent is looking at the environmental impact of aqueous methods for electronics cleaning. One challenge he noted with this application was the cost for waste water treatment because water cleaning requires "different equipment, dryers, and waste water treatment."

Azeotropic Mixture. A respondent from India is investigating an azeotropic mixture to replace CFC-12 in refrigeration equipment. The respondent is analyzing thermodynamic properties, vapor compression cycles, and material compatibility issues. In the respondent's opinion, the cost and lack of the potential azeotropic compounds he is studying are minor problems.

Ethylchloride. A respondent from Austria is investigating ethylchloride as a replacement for CFC-22 in heat pumps for refrigeration applications. The respondent is studying the thermodynamic properties, vapor compression cycle 
analyses, materials compatibility, and reactivity issues. Problems include technology modifications to address compatibility problems with aluminum, environmental issues, and limited applications.

H2O-LiBr. A respondent from France is analyzing a water/lithium/ bromide mixture as a replacement for CFC-12. He is currentiy in the "first year of study of a 4-year development plan." Specifically, he is investigating the potential of using a water/lithium bromide mixture as a refrigerant by studying the materials compatibility issues and its potential for what he referred to as a "hybrid cycle" that combines both the absorption and vaporcompression refrigerant cycles. A simulation program and bench study have been completed. Some problems he cited include the many technology modifications required to develop the hybrid cycle, its high expected first cost, and its limited applicability.

Binary Mixtures. Three respondents from Canada are working together to analyze various two-component mixtures of HFCs and HCFCs for applications in refrigeration systems. They are analyzing both the thermodynamic properties and the vapor-compression cycle efficiency of the binary mixtures. They hope to develop compounds that require little or no modifications to existing air-conditioning equipment (i.e., a "drop-in" substitute).

HCFC-123. A respondent from Japan is looking at HCFC-123 as a replacement for CFC-11 as a foaming agent for insulation in refrigerators. His goal is to make refrigeration insulation with the same insulating value and cost as CFC-11, but he is finding it "very difficult." The insulation he has tested, which is made using HCFC-123, lacks "high quality."

A respondent from Italy reported testing the use of HCFC-123 in geothermal power cycles. The respondent has "measured the vapor pressure and performed some preliminary test[s] on thermal stability up to $200^{\circ} \mathrm{C}$. "The respondent notes that "in [the] system (a hot-water power cycle), changing from CFC-11 to HFC-123 should not pose real problems, except...some compatibility problems with materials [may] arise."

HCFC-141b. Two respondents, one from Korea and orle from Taiwan, are investigating HCFC-141b as a replacement for CFC-11. The respondent from 
Korea is also studying how to manufacture HCFC-141b in large quantities (1.e., an "industrial manufacturing process of HCFC-141b"). The Taiwanese respondent is testing the application of the compound as an electronics cleaner and insulation/blowing agent. Some of the problems with using HCFC-14lb that were cited by these respondents include its higher cost, flammabllity, required technology modifications, limited applications, and legal issues. The respondent is planning to study how to manufacture the alternative.

HFC-152a. Individual respondents from Canada, Germany, and the United Kingdom are looking at HFC-152a as an alterative to CFC-12. A 11 three respondents are studying the applications of the compound in vapor-compression cycle refrigeration systems. The respondent from Canada is also testing its applicability as a foaming agent for insulation. All resporidents mentioned that the major problems with the compound are its flammability and the associated product liability issues.

The respondent from Canada noted, "We believe that the alternate will be viable, assuming materials compatibility (as it effects long-term reliability) doesn't berome an issue." Future plans include completing long-term life cycle testing and field trials.

The primary goal of the German respondent's research is to test thermodynamic properties, analyze HFC-152a vapor-compression refrigeration cycles, and identify and resolve materials compatibility issues. The German respondent noted that because the alternative sti11 has 1\% GWP (however, no ozone depleting potential), environmental issues are still a concern. He further stated that lubricity, lack of supply (the compound is a byproduct of an $0 i 1$ cracking process), and the limited applications of HFC-152a are issues, but of secondary importance. Research funding in Germany, in his opinion, is a moderately serious problem at this time. The respondent noted that "several projects funded by the German government will end during this year. The money from the German government will be spent mainly for projects in East Germany."

Mixture of HFC-152a and HFC-134a. One of the respondents from Germany is looking at a mixture of HFC-152a and HFC-134a to replace CFC-12. The 
primary goal of his research is to investigate the thermodynamic properties. He noted that lubricity is a moderately serlous problem.

Hydrogen. A respondent from Germany is investigating hydrogen as a propellant that is stored in a metal-hydride compound as a replacement for CFCs in aerosol spray cans. Specific activities include tests to determine "dependence of aerosol quality on propellant pressure... and leakage of propel. lant out of commercially available spray cans." Technology issues needed to further this application include "higher [working] pressures, modified [spray] nozzles, and the need for additional metal-hydride storage, manufacturing, and recycling (reclaiming)."

Isobutano. A respondent from Mexico is examining the use of "Isobutiano" as a replacement for CFC-11 in aerosols. He indicated that technology modifications are a moderately serious problem and flammability is a very serious problem. "Aerosol filling technology must be modified to take into account flammable substitutes."

Nonazeotropic refrigerant mixtures (NARMs). The use of NARMs (e.g., HFC-22/HFC-142b) as potential replacements for CFC-12 is being studied by a Swedish respondent. The primary goal of the research is to test the application of the NARM in heat pumps by conducting vapor compression cycle analyses and testing heat transfer properties. A significant technical challenge is to develop a suitable evaporator design for the two temperature evaporative process that are characteristic of a NARM. Future plans include "testing full-sized heat pumps [and] the evaporative heat transfer process, modeling [NARMs] with oil, arid [then] refining cycle calculations."

Ammonia. Ammonia, long used in industrial refrigeration processes worldwide, is currently being studied in Norway, Sweden, and the United Kingdom for wider commercial air-conditioning and refrigeration applications.

The Norwegian respondent is studying the compound as an alternative for both CFC-12 and CFC-502. The primary goal of his research is to analyze vapor compression cycles at temperatures and pressures typical for commercial refrigeration equipment. "A prototype of a compact ammonia refrigeration unit... is under construction." Because ammonia is not compatible with 
copper, the most common heat transfer material used in refrigerant heat exchangers, selection of new construction materials will be necessary. Other needed technical modifications include implementation of a method to prevent ammonia gas from escaping into occupted spaces. Finally, a basic problem hindering the use of ammonia is the "lack of ammonia tradition and experience in some countries."

The respondent from Sweden is studying "ammonia in mechanical refrigeration combined with liquid nitrogen and carbon dioxide" for industrial food freezing.

The United Kingdom respondent has made an assessment of necessary plant changes and provided guidance on the safe use of ammonia. The main issue associated with current ammunia-based technologies "is providing [adequate] safety systems when [they are] used for building air-conditioning applications." The most serious obstacle in his view is "lack of industry skills in using [ammonia] and an aversion of [the air-conditioning] industry and users."

Water. A respondent from Germany is studying using water at applications above $0^{\circ} \mathrm{C}$ as a replacement vapor-compression cycle refrigerant for CFC-11, CFC-12, and CFC-114. Though the specific uses for which a water-based system could be applied were unclear from the survey answers, the respondent indicated that a large-scale plant that uses water as the refrigerant has been completed, and is now a commercially available technology. He did indicate he wi11 continue to improve the components of the system.

Terrary Blend (HCFC-22, HFC-124 and HFC-152a). A respondent from the Netherlands is investigating the DuPont "ternary blend" as a replacement for CFC-12 in refrigeration equipment. He noted that fiammability is a possible problem.

ISCEON 69S. A respondent from the United Kingdom has developed a nonCFC refrigerant that is now on the market called "ISCEON 69S, " a blend that includes HCFC-22, propane, HFC-218, and is marketed as a replacement for CFC-502 in refrigeration equipment. The respondent indicated that no technology modifications are necessary to existing CFC-502 equipment, which would make this one of the few potential "drop-in" alternatives. 


\subsection{ISSUES}

About half of the respondents reported that modifications to technologies currently using CFCs would be required to use the alternative compounds they were studying. That is, there is no direct "drop-in" non-CFC alternative refrigerants. The most frequently cited issue associated with the transition to CFC alternatives was "technology modifications." One third of these respondents qualitatively rated technology modifications as a moderately sertous issue.

Cost of the alternatives and of their implementation was the second most frequently mentioned issue from the 1 ist, with most of the respondents indicating it to be either a moderately serious or minor problem. Finally, just under half of all respondents said lubricity is a problem, with most claiming it to be a moderately serious problem. Table 3.5 lists the problems associ. ated with the alternative research.

TABLE 3.5. Specifled Problems/Issues Identified With the Research

\begin{tabular}{lcccc} 
Problem/Issue & $\begin{array}{c}\text { A11 } \\
\text { Respondents }\end{array}$ & $\begin{array}{c}\text { HFC-134a } \\
\text { Respondents }\end{array}$ & $\begin{array}{c}\text { HCFC-22 } \\
\text { Respondents }\end{array}$ \\
\cline { 2 - 3 } Cost & $61 \%$ & $93 \%$ & $86 \%$ \\
Environmental Issues & $33 \%$ & $48 \%$ & $43 \%$ \\
Technology Modifications & $63 \%$ & $86 \%$ & $72 \%$ \\
Limited Applications & $38 \%$ & $45 \%$ & $57 \%$ \\
Lack of Supply & $37 \%$ & $52 \%$ & $43 \%$ \\
Lubricity & $48 \%$ & $79 \%$ & $43 \%$ \\
Efficiency & $37 \%$ & $62 \%$ & $43 \%$ \\
Legal Issues & $28 \%$ & $35 \%$ & $29 \%$ \\
Funding & $31 \%$ & $38 \%$ & $43 \%$ \\
Nother & $21 \%$ & $10 \%$ & $14 \%$ \\
None & $1 \%$ & $0 \%$ & $0 \%$
\end{tabular}




\section{$3.4 .1 \quad H F C-134 a$}

Three quarters of the respondents studying HFC-134a specifically indicated that technology modifications to existing CFC vapor-compression cycle equipment would be required in order to use HFC-134a as an alternative refrigerant.

As can be expected given the large number of respondents researching HFC-134a/oil mixtures, over half of the respondents replied that 011 compatibility was an issue. Several other respondents mentioned that the heat transfer equipment used in vapor.-compression cycle equipment would need modification to account for the heat transport properties of HFC-134a. Other issues related to using this alternative in current CFC vapor-compression cycle equipment include refrigerant desiccant effectiveness; design of components such as tubes, seals, and hoses; and use of materials such as plastics, metal and copper. Individual respondents also mentioned (but did not elaborate upon) problems with compressor-motor insulation compatibility in hermetic systems, energy efficiency, reliability, electrical resistivity, and leaking.

As shown in Table 3.5, the most frequently cited issues associated with the use of HFC-134a were its cost, technology modifications, and lubricity. of these three, most of the respondents indicated the severity of these problems was "moderate." About half of the respondents indicated as problems the lower operational efficiency of HFC-134a relative to (presumably) CFC-12, its lack of supply, environmental issues, and its limited application. Less frequently mentioned problems include legal issues and difficulty in obtaining research funding.

\section{4 .2 HCFC -22}

Increased cost was the most frequently mentioned problem indicated by the respondents who are researching HCFC-22. This finding seems at first surprising, for HCFC-22 is commonly used in many refrigeration and airconditioning applications, and thus would be expected to be relatively inexpensive to adapt to similar applications where CFCs are currently used. It is, however, about twice as expensive to manufacture as, for example, CFC-12 or CFC-11. In addition, a vapor-compression HCFC-22 cycle operates at higher 
pressures for the same temperatures than a similar CFC-12 cycle, which would increase the production cost of system components. The cycle efficiency of HCFC-22 is also lower than CFC-12 or CFC-11, resulting in higher energy usage for the same capacity. Finally, its different refrigeration effect and operating pressures clearly would require redesign of compressors and heat exchangers in refrigeration applications that use CFCs, as well as extensive retooling of manufacturing facilities. However, because operation of HCFC-22 in air-conditioning and refrigeration is, as already stated, well understood, more innovative technology modifications to adapt it to applications as a replacement for CFCs do not appear to be necessary. As one survey respondent said "design modifications are necessary but on the same technology base."

"Limited applications for HCFC-22" was also mentioned as a froblem. However, no details were given in the surveys

\subsection{RESEARCH PLANS}

The responses varied to the question inquiring about future research studies. Several respondents $\mathrm{plan}$ to study heat transfer in the condensation and evaporation of refrigerant mixtures. Other studies include studying alternative refrigeration cycles to the vapor-compression cycle (e.g., Brayton cycle), redesigning centrifugal chillers, and developing compressors that are optimized for use with alternative refrigerants. Other general research plans include the following: studying ways to improve CFC containment to minimize losses to the environment, recycling existing CFC supplies to extend their useful life, determining the suitability of alternatives as "drop-in" substitutes in existing CFC-using refrigeration systems, studying flammability issues relating to alternatives, improving energy efficiency in airconditioning equipment, studying foam blowing, and researching the condensation and evaporation of NARMs. One respondent is also beginning tests using a new type of CFC recovery/recycling machine. The overall objective of current and future research being conducted by one respondent from the United Kingdom is "to assess the implications of the CFC phaseout for the U.K. building 
industry, with particular emphasis [on] providing guidance on new [alternative] refrigerants, changes to performance, and costs, including equipment conversion."

It is interesting to note that of those respondents who indicated that HFC-134a offers the most potential for alleviating the CFC problem, almost all of the respondents said that their future plans entail studying other alternatives. This finding suggests that HFC-134a may not be an appropriate alternative to CFCs in some applications. Of these respondents, most indicated that they will be investigating alternatives to HCFC-22. A few expect to be evaluating alternatives to R-502 (an approximately 50/50 blend of HCFC-22 and CFC115) and other alternatives to CFC-11. Some promising alternative fluids these researchers expect to be studying include ammonia $\left(\mathrm{NH}_{3}\right)$ and $\mathrm{HFC}-152 \mathrm{a}$.

\subsection{RESEARCH THAT SHOULD BE PURSUED}

Table 3.6 lists other groups and organizations, specified by the respondents, that are conducting research into CFC alternatives. When asked what type of research should be pursued by these groups, several respondents indicated additional theoretical vapor-compression cycle analyses should be performed. Several respondents also felt that the flammability issues with some of the alternatives needed to be addressed. A few mentioned the need for further study of the potential environmental effects of CFCs including global warming and ozone depletion. Retrofitting the existing CFC systems for alternatives, developing drop-in alternatives, and conducting long-term reliability tests of systems using the alternatives were also mentioned. One respondent. mentioned the need for looking at low-cost production methods. Finally, a few respondents also mentioned the need for increased international cooperation and "intentional" collaboration in the study of CFC alternatives. (a) This final suggestion could be quite advantageous given that the research progress between various countries appears to differ significantly.

(a) One example of an international on-going collaborative research activity is the "Alternative Fluorocarbons Environmental Acceptability Study" (AFEAS) (1991). This work is co-funded by 12 of the world's chemical companies. 
TABLE 3.6. Other Groups/Organizations Conducting CFC Research

\begin{tabular}{ll} 
Country & \multicolumn{1}{c}{ Groups/Organizations } \\
Austria & $\begin{array}{l}\text { Forschungrzentrum Seikersdorf } \\
\text { Aubeninstitut, Techn Univ., Vienna }\end{array}$ \\
Brazil & All big refrigerator companies under ABINEE (Industry \\
& association) \\
Germany & DKV (German Refrigeration and AC Society - Deutscher \\
& Kalte- UND Klimatechnischer Verein, Pfaffenwaldring 10, \\
& D-7000 Stuttgart fax 0711/685.3242) \\
& Various companies (Hoechst, Basf, Kali Chemie, Huls Ag \\
& etc.) \\
& Universities of Hannover, Narls Ruhe, Nunchen, Dresden \\
& Keio University \\
Kobe University & National Chemical Laboratory for Industry \\
& Freon Companies (Asahi Glass, Daikin, Showa Denko) \\
& Japanese Association of Refrigeration \\
& IMACC (Mexican Aerosol Institute) \\
Mexico & Heat pump Center - Sittard, NL \\
The Netherlands & TNO- Apledoom - NL \\
& University of Delft - Delft, NL (absorption processes) \\
& ICI Phone Pooling \\
& Dupont \\
ICI C\&P, The Heath, Runan, England \\
National Engineering Laboratory, East Kilbride
\end{tabular}

Most of the HFC-134a respondents wanted to see more research into the thermodynamic and transport properties of other alternatives and more testing of HFC-134a/lubricant mixtures for vapor compression cycle equipment. Another material compatibility issue cited by one researcher regarded reactivity of alternatives.

\subsection{FUNDING}

Over half of the respondents did not answer the research budget questions, perhaps indicating that funding is a sensitive issue. 


\section{7 .1 Funding Levels}

Those that answered the funding question reported a wide range of funding levels, ranging from $\$ 1,000$ to $\$ 4$ million U.S. dollars. Because the question asked for the research budget for 1990, the exchange rates for the first working day of 1990 were used for this analysis. Table 3.71 ists the exchange rates for each country. West Germany's rate was used for Germany's exchange rate. Table 3.8 shows the total dollar amount (in U.S. dollars), the median amount, the range of reported budgets, and the number of respondents for each country. Japan, Germany, Canada, and the United Kingdom had the greatest number of respondents answering the question. However, the range and the median amounts widely varied. Norway and Austria each had one respondent who answered the question, yet they had relatively large budgets.

\section{7 .2 Funding Sources}

As shown in Table 3.9, about half of the respondents receive their funding from industry, followed by government, other sources, and universities. A few said funding would decrease, while most said funding would remain stable over the next year. With a few exceptions, similar trends were found when the data were analyzed by specific compound and by country. The German responses to the stability of the funding level were mixed: $40 \%$ thought that funding would decrease in the next year; however, $30 \%$ felt that it would remain stable. Over one-third of the United Kingdom respondents felt funding would decrease. Of the five Canadian respondents that answered the funding source question, four indicated they receive funding from the government, while two indicated industry.

\subsection{RESEARCH DISSEMINATION}

Presentations at technical conferences were the most common method cited by respondents for learning the research results of others. Journals were the second most common method. In Canada, professional organizations are the most common method for learning of research by others. 
TABLE 3.7. Exchange Rates, January 2, 1990

(Wall Street Journal 1990)

\begin{tabular}{ll} 
Country & Exchange Rate \\
\hline Australia & 0.784 \\
Austria & 0.8294 \\
Brazil & 0.11495 \\
Canada & 0.8613 \\
China & 0.211774 \\
Denmark & 0.15 \\
France & 0.1707 \\
Germany (West) & 0.5834 \\
India & 0.05952 \\
Italy & 0.0007777 \\
Japan & 0.006825 \\
Korea & 0.0014684 \\
Mexico & 0.0003735 \\
New Zeatand & 0.593 \\
Norway & 0.1506 \\
Sweden & 0.1605 \\
Switzerland & 0.6315 \\
Taiwan & 0.038505 \\
The Netherlands & 0.5166 \\
United Kingdom & 1.605 \\
&
\end{tabular}


IABLE 3.8. Research Budgets by Country

Total Budget

\begin{tabular}{|c|c|c|c|c|}
\hline Country & In U.S. \$ & Median & Range & Respondents \\
\hline Australia & 414,700 & 414,700 & 414,700 & 1 \\
\hline Austria & 78,400 & 78,400 & 78,400 & 1 \\
\hline Brazil & 300,000 & 300,000 & 300,000 & 1 \\
\hline Canada & 568,458 & 142,115 & $68,000-215,325$ & 4 \\
\hline China & 1,000 & 1,000 & 1,000 & 1 \\
\hline Denmark & 320,000 & 160,000 & $20,000-300,000$ & 2 \\
\hline France & 341,400 & 170,000 & $85,350-341,400$ & 2 \\
\hline Germany & $1,502,255$ & 116,680 & $14,585-1,166,800$ & 5 \\
\hline India & 5,952 & 5,952 & 5,952 & 1 \\
\hline Italy & 40,000 & 40,000 & 40,000 & 1 \\
\hline Japan & $6,590,225$ & 568,250 & $20,475-4,000,000$ & 6 \\
\hline Korea (South) & 300,000 & 300,000 & 300,000 & 1 \\
\hline Mexico & 0 & 0 & 0 & 0 \\
\hline New Zealand & 0 & 0 & 0 & 0 \\
\hline Norway & 753,000 & 753,000 & 753,000 & 1 \\
\hline Sweden & 530,000 & 265,000 & $200,000-330,000$ & 2 \\
\hline Switzerland & 63,150 & 63,150 & 63,150 & 1 \\
\hline Taiwan & 0 & 0 & 0 & 0 \\
\hline The Netherlands & 250,000 & 250,000 & 250,000 & 1 \\
\hline United Kingdom & 170,130 & 36,915 & $16,050-80,250$ & 4 \\
\hline
\end{tabular}

TABLE 3.9. Funding Sources

\begin{tabular}{lc} 
Funding Source & Respondents \\
\cline { 2 - 2 } Government & $30 \%$ \\
University & $6 \%$ \\
Industry & $48 \%$ \\
Other & $15 \%$
\end{tabular}




\subsection{CONCLUSIONS AND RECOMMENDATIONS}

The results of the survey provide a current overview of international research activities into alternatives for CFCs.

\subsection{CONCLUSIONS}

The following conclusions can be drawn from the data:

- Length of Research. Most of the international research has been ongoing for more than 3 years, and the respondents expect to continue their research for at least another 3 yaars.

- Identification of Alternatives. The most prevalent alternatives being studied by the respondents were HFC-134a and, to a lesser extent, HCFC-22. Over one-third of the respondents reported the alternative HFC-134a as having the most potential for alleviating the CFC problem.

- Purpose of the Research. Most of the respondents indicated that they are currently investigating the application of one or more CFC alternatives to vapor-compression cycle refrigeration/airconditioning equipment.

The compound HFC-134a was frequently cited as a replacement for C.FC-12, which is currentiy used extensively in refrigeration, water chilling, and car air-conditioning applications.

of those respondents who indicated HCFC-22 as the main compound they are studying, most are studying vapor-compression equipment applications

- Issues. Three quarters of the respondents studying HFC-134a specifically indicated that technology modifications to existing CFC vapor-compression cycle equipment would be required in order to use HFC - $134 \mathrm{~A}$ as an alternative refrigerant. In addition, over half of the respondents replied that oil compatibility was an issue. Increased cost is the most frequently mentioned problem indicated by the respondents who are researching HCFC-22.

- Research Plans. Future research plans were quite varied. Several respondents plan to study heat transfer in the condensation and evaporation of refrigerant mixtures. Of those respondents who indicated that HFC-134a offers the most potential for alleviating the CFC problem, almost all said that their future plans entail studying other alternatives. The finding suggests that HFC-134a 
may not be an appropriate alternative to CFCs in some applications. of these respondents, most indicated that they will be investigating alternatives to HCFC-22.

- Research That Should Be Pursued. Several respondents indicated that additional theoretical vapor-compression cycle analyses should be performed. Several respondents also indicated that the flammability issues with some of the alternatives needed to be addressed.

- Funding. The respondents reported a wide range of funding levels, ranging from $\$ 1,000$ to $\$ 4$ million U.S. dollars. About half of the respondents receive their funding from industry, followed by government, other sources, and universities. A few said funding would decrease, while most said funding would remain stable over the next year.

- Research Dissemination. Presentations at technical conferences were the most commion method cited by respondents for learning about the research results of others.

\subsection{RECOMMENDATIONS}

The Montreal Protocol represents an unprecedented example of the ability of nations to cooperate and collaborate on issues of international concern. Much could be done to foster this expressed desire to cooperate on the CFC issue. Moreover, considerable interest in the results of this study was expressed by the respondents as evidenced by affirmatively answering the question whether they would like a copy of this report and by the relatively high response rate for an international survey written in English. The research community would probably welcome an expanded cooperative effort such as an international network or organization devoted solely to CFC alternatives developments. This network could be as simple as a newsletter describing current research efforts and results or as elaborate as an organization. Both types of networks would improve communication among the international CFC research community.

An issue needing further study is the development of technologies that are compatible with the new alternatives. Although this survey touched upon this issue, a more in-depth study would illuminate the entire range of technology developments, their purpose and problems, and chance of wide-spread use. Such a study could also help to identify opportunities for technology 
development. International collaboration in this effort colld open many opportuntties for applications of current or planned technnlogy development or modification. 


\subsection{REFERENCES}

Marsetlle, T. J., and M. C. Baechler. 1990. Chlorofluorocarbon Environmental Issues Related to conservation Acquisition in Commerctal Butldings. PNL. 7503, Pactfic Northwest laboratory, Richland, Washington.

Moore, T. 1989. "The Challenge of Doing Wt thout CFCs." EPRI Journal $14: 4-13$.

Rowland, F. S., and M. J. Molina. 1975. "Chlorofluoromethanes in the Environment." Review of Geophysical Space Physics 13:1-36.

The Wall Street Journal. January 3, 1990. $\operatorname{CCXV(2):C12.~}$

U.S. Environmenta1 Protection Agency. 1987. Impact on Ozone Attainment of CFC Controls Used to Prevent Future Deplettion of Stratospheric Ozone. EPA600088074, EPA Research, Trlangle Park, North Carolina.

World Meteorological Organization (WMO). 1985. Atmosphertc Ozone 1985:

Assessment of our Understanding of the Process Controlling Its Present Distribution and Change. Report No. 16, Vol. III, Global Ozone Research and Monitoring Project. 
APPENDIX A

QUEST IONNAIRE 
1. Do you or your organization conduct (or have you conducted) research into alternatives to chloro/luorocarbons (CFCs)?

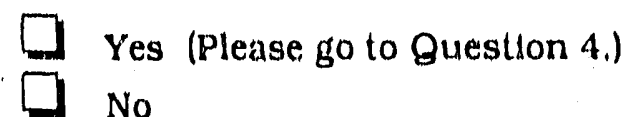

2. If no, can you provide names and addresses of researchers unuolved in this area of study in your country?

Narne:

Title:

Institution/Agency:

Address:

3. In other countries?

Name:

Title:

Institution/Agency:

Address:

4. When did you begin conducting this research?

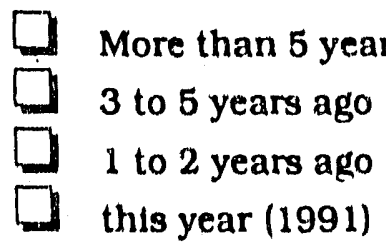

5. How long will you be conttnutng with this research?

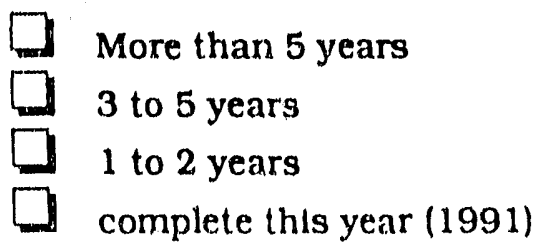


6. What altemattue chemical compounds have you studied and what CFCs are they supposed to replace?

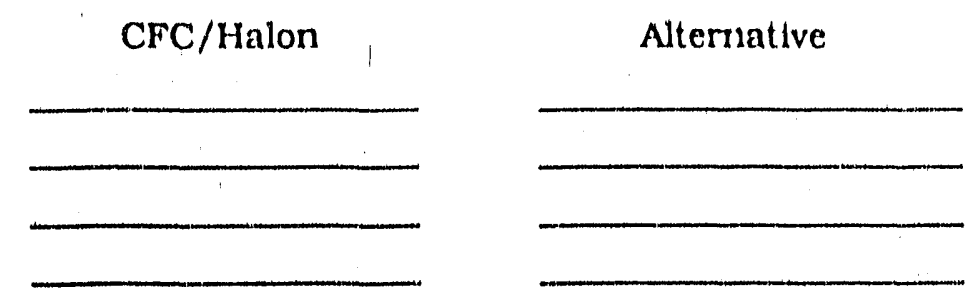

For questions 7 through 10 . please select the one CFC alternatve you have been studying that you feel has the most potentlal for alleviating the CFC problem. The alternative you will be referring to is:

7. What are the primary goals of this research? Please check all those that apply.

To test applications of the compound

D refrigeration/air conditioning

[insulation/blowing agent

a electronics cleaner

$\square$ fire extingulsher

a other

To test propertles of the compound itself
D thermodynamlc properties
$\square$
vapor compression cycle analyses
materials compatibulity
reactivity
environmental impact
other (please specify) 
8. What is the status of your research to date? (Please include any results to date.)

9. If your research is application specific, will it be necessary to modify existing CFC technologies in order to use the alternative compound?

Yes

No

Please explain:

10. Whai are the disadwantages or problems, if any, of using this alternative compound instead of using CFCs? Please tndicate the extent of the problem:

$1=$ Very serlous problem

2 = Moderately serlous problem

$3=$ Mtnor problem

cost

environmental (please specify)

technology modufications

limited application

lack of supply

lubricity

efficiency (please specify)

legal

funding

other (please specify)

none 
11. What was your research budget for CFC alternattues for 1990 ? (Please indicate the currency)

11a) From what sources does your funding come? Please specify the name of the organization.

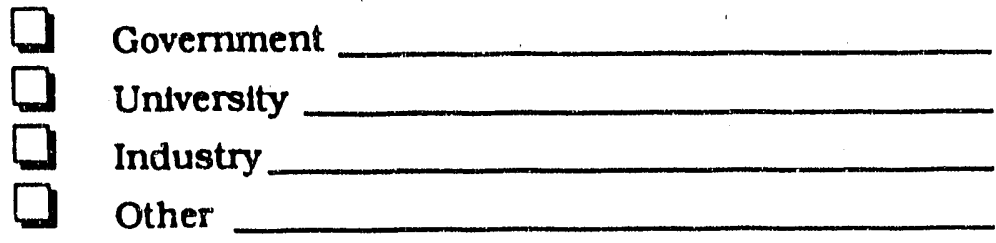

11b) In the next year, do you expect this funding to (please check one)
$\square$ increase
$\square$ decrease or
$\square$ remain stable?

Please explain:

12. What are your plans for future studies for alternatives to CFCs?

$$
\therefore \wedge
$$


13. What other groups or organizations are involved with CFC research in your country?

13a) What other groups or organizations are Involved with CFC research in the international community?

14. In your optriton, what type of research should these groups pursue?

15. How do you hear about the research results in $C F C$ altematives of other researchers? Please rank from the mast common (1) to the least comrnon (4) method.

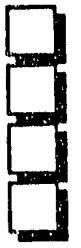

presentations/conferences

journals (please name)

organizations (please name)

other

16. We expect our report will be completed by September 1991. Would you like to recelve a copy of this report?
$\square$ Yes
No

Thank you for completing this survey. Pleasie return in the enclosed envelope by April 30, 1991.

A. 5 
APPENDIX B

COVER LETTER 


\section{Battelle}

Pacific Northwest Laboratories Battelle Boulevard

P.O. Box 999

Richland, Washington 99352

Telephone (509)

March 20, 1991

Dear

The Pacific Northwest Laboratory is conducting a study to document foreign research activities on chemical compounds that present alternatives to chlorofluorcarbons (CFCs). The study is being done for the United States Department of Energy as part of their International Research Monitoring program. The Department of Energy plans to use this information to gain a global perspective on CFC research. Our initial research efforts identified you as a possible contact for our study.

The enclosed questionnaire was designed to gather general information about foreign research on CFC alternatives. We are interested in the types of research being conducted; the results of the research; problems encountered; and future studies that are planned. If you would like a copy of our final report please indicate as such on the space provided on the questionnaire and we will be happy to send you a copy.

We would greatly appreciate your input to this questionnaire. We would also like to receive copies of any reports you have on your CFC research, and we would like the names of other researchers we should contact. Please contact Alison Thurman at 509-376-4118 (phone) or 509-376-5484 (fax) with any questions or comments you may have about the questionnaire. Please return the questionnaire in the enclosed envelope by April 30, 1991. Thank you for your time and effort.

Sincerely,

Sean C. McDonald

Senior Research Economist

SCM: agt:mrp

Enclosure 


\section{APPENDIX C}

QUESTIONNAIRE DISTRIBUTION LIST 


\section{AUS'TRALIA:}

Chris Baker, Manager, Ozone Unit E.PA

477 Collins

Melboume, Victoria

3000

AUSI'RAIIA

Robert L. Muston, President

Environmental Products

Amalgamated Pty. Lid

5-25 Calaster Street.

P.O. Box 191

Shepparton, Victoria

AUSTRALIA

\section{AUSTRIA:}

M. Narodoslawsky, PhD Institute of Chemical Engineering Graz University of Technology 8010 Graz

AUSTRIA

Mark Schneeberger

D1. Dr. techn,/member of the board Kraftwerke AG, (OKA) 4020 Linz Boehrnerwaldstrasse 3 AUSTRLA

\section{BRAZIL:}

Alberto Carrizo, Director Climax Development Iechnological Av. Jose Pereira Lopes 250 13560 Sao Carlos-SP BRAZIL

Ernesto Heinzelmann, R\&D Director Embraco SA

Rua Rui Barbosa, 1020

89200 Joinville

BRAZII.

Milton Edson Lubraico Ford Molor Cornpany

Az. Orlanda

Bergamo, 1000-1200

Cepo 7220, Guorulhoe, SP

BRAZIL

Paulo Vieira

Du Pont

Al lapecuru 506-Alfazil

Cepo 0400 CP 26

BRAZII.
Paulo Vodianitskala, Manager

Systems Englneering

Consul SA

Caixa Postal 267/269, CEP89200

892,00 Joinville SC

BRAZIL

\section{CANADA:}

Michael R. Ascough

Du Pont Canada

Box 2200, Streetsville

Mississauga, Ontario LSM2H3

CANADA

Mark T. Bomberg

National Research Council of Canada

DuPoint Canada

Box 2200, Streetsville

Mississauga, Ontario L2M2H3

CANADA

Colleen M. Bryclon

DuPont Canada

Box 2200, Streetsville

Mississauga, Ontario, L.5M

CANADA

Victor Buxton, Chief

Chemicals Controls Branch

Environment Canada

351 St. Joseph Blvd.

Hull, Quebec, Ontario K2H5N9

CANADA

Art Fiizgerald

Northern 'Telecom

3 Robert Speck Parkway

Mississauga, Ontario I.AZ3C8

CANADA

Stephen R. Griffin, Mgr.

Product Engineering

W. C. Wood Co., I id.

P.O. Box 750

5 Arthur Strect $S$.

Guelph N1H 61.9

CANADA

Vilvan Gunasingham

Ford Electronics Mfg. Corp.

7455 Birchmount

Marcham, Ontario L 3 R5C2

CANAIA
Margaret Kerr, Vice President Environment, Heallh and Salety Northern Telecom

3 Robert Speck Prrkway

Mississauga, Ontario L4Z3C8

CANADA

Paul A. I.nRue

CRIQ

P.O. Box 9038

Ste-Foy, Quebec G1VAC7

CANADA

Timothy Leah, Head

Use Paltern Section

Commercial Chemicals Branch

Environment Canada

351 St. Joseph Blvd.

Hull Quebec, Ontario Kal.15No

CANADA

Adrien J. LeBlanc

Manufacturing Process Iechunlogy

Northern Telecom

3 Robert Speck Parkiway

Mississauga, Ontario 1.423C8

CANADA

Peter Lensch

OCS-SM'T Automation

121 Montec Be Liesse

St. Laurent, Quct ec 1447156

CANADA

Jeffrey Linton, Research Officer Natl. Res, Council Canada

M17, Montreal Rd.

Ottawa, Ontario K1AORG

CANADA

Zal Portnoy

Carrier Canada Lid.

101 Claireville Dr.

Rexdale, Ontario M9W oK9

CANADA

Pierre Renaud

CRIQ

333 Franquel

Post Office Box 90.38

SIe-Foy, Qucbec (il VAC:7

CANADA

Keith Snelson, Research officer

Nall. Res. Council Canada

M17 Montreal Rd.

Ollawa, Ontario KIAORG

CANADA

C.I 
Art Stelzig, Chief

Chemical Industries Dlvison

Environment Canada

351 St. Joseph Blvd.

Hull Quebec, Ontario K2H5No

CANADA

CHINA:

Cac Desheng, Sr. Engineer

Chinese Ass. Refrigeration

Department Leader of Office

11, Fu Cheng Road

100037 Beijing

CHINA

Yu Bing Feng, PhD

Assistant Professor

AC Group, Department Power Mach

Zl'an Jiaotong Universily

Xi'an (Shatanxi)

CHINA

Ren Jin Lu, Senior Engincer

Refrigetation Group

General Mach. Research Institute

Shushan Road, P.O. 230031

HFel

CHINA

\section{DENMARK:}

H.C. Aagaard

Danish Technological Institutc

Gregersenszej, P.O. Box 141

2630 Thastrup

DENMARK

Per O. Danig, Associate Professor

Refrigeration Laboratory

Technical University, Blug. 402B

2800 Lyngby

DENMARK

Hans Knudsen, Managing Editor

A'Gramkow

Augustenborg Landeij 19

6400) Soenderbors

DENMARK

Erik Korfitsen, Manager R\&I)

Development Departruent

Industry Division

Sabroe Refrigeration $\mathrm{A} / \mathrm{S}$

P.). Box 1810

8270 Hojbjerg

DI:NMARK
FRANCE:

Claude Brtan

European Development Munager

Dehon Group

Refrigeration Department

26 Ave. dupelle Parc

94683 Vlnecnnes

FRANCL:

Denis Clodic, Project Leader Centre D'Energetique Ecole Des

Mines de Paris

60, BD St. Michel

75272 Paris, Cedex 06

FRANCE

Brian Elis, Director

Protonique SA

P.O. Box 78

Romanel-Sur-Luasanne CH-1032

FRANCE

\section{GERMANY}

H.D. Baehr, PhD, ho Institute of 'Thermodynamics

University of Hannover

Callinstrasse 36

3000 Hannover 1

GERMANY

Ingrid Hanhoff-Stemping

Umwektbundesamt

Bismark Platz 1

1 Berlin 33

GERMANY

Paut Erik Hansen, PhD, Manlager

D. anfoss Ombl]

Reliability and Libs

Mads Clausenstrasse ?

D2390 Fiensburg

GERMANY

Ullrich Hesse

University of Hannover

Wel Fen Garten $1 A$

Hannover, FR 3000

GERMANY

Werner Jensen

Consultant

Integral Teuhnologic: (imblt

Lise-Meiner Str.2

Leberstrasse: 3

D.2390 Fensburg

GEIRMANY
Juergen Pocklington

Shel!

Deutsche She:lag

Pae-Laboratory

2000 Hamburg 93

GERMANY

Michacel Kintfecl

Universliy of llannover

Institute Luer Kaelteteumk

Welfangarten $1 \mathrm{~A}$

D.3000 Hannover

GERMANY

Horst Kruse, PhD, Professor

Inst. Kacltetechnilk

University of Hannover

3000 Hannover 1

GERMANY

Gunter Langer

Battelle Europe

An Romerhof 35, D-(0)(0)

Frankfurt Main

GERMANY

Klaus W. Menze, Mannager

Heat 'Iransfer Eng.

Wieland-Werke $A C$

Post Office Box 4240

D.7900 ULM

GERMANY

J. E. Nonnenmann, PhD

Sudd Kuehlerfabr Behr cimbll

Mauserstrasse 3

D.7000 Stuttgart 30)

GERMANY

Wolfgang Scholten

Hoechst AG

Postlox 800320

D-6230 Frankfurt

GERMANY

Rolan Burk

Behr OmbH \& Co.

Mauserstrasse 3

7000) Stutlgart 30

GERMANY

INDIA:

R. S. Agarwal, PhD, Professor

Department of Mechanical

Engineering

Indian Institule of 'Pechnology Delli

Ilatu:-Khas

New Delli 110010

INIDIA 
S. C. Bhaduri, PhD

Assistant Prolessor

Instltute of Mechanlcal Engineering

Indian Institute of Technology

lowal

Bombay 400076

INDIA

Sukumar Devotta, PhD, Director

Chemical Engineering Division

National Chemical Laboratory

Pune 411008

INDIA

Mr. K Madhava Sarma

Additlonal Secretary

Ministry of Environment and Forests

Government of India

CGO Complex, Lodi Road

New Delhl 110003

INDIA

ITAIX:

Gianfranco Angelino, PhD

DIP. Professor Encrgetic

Polltecnico

Plazzal Leonardo da Vinci, 32

Milano 20133

I'ALY

Glogio Giuffrida

Necchi Compressori S.R.L.

Viale Della Repub. 10

Pavia 27100

[TALY

Mario Segagıi

Necchi Compressori S.R.L.

Viale Della Repub. 10

Pavie 27100

ITALY

JAPAN:

Akari Aguri, Director

Frood Proc. Affair

Daikin Plant Lid.

3.5.11, Nihonbashi-Honcho

Chuo-Ku

'ookyo 103

JAPAN
Tadatoshi Banse, Manager

Engincering \& Plannilig Departmen 60335

Air Condition \& Appllance Croup

'Loshiba Corp., Comsumer Products

2-1. Shibnura 1.Chome

Minato-Kull

'ikkyo 105

JAPAN

Yoshlyukd Ishil

Sr. Engineer of Env'l Center

Hitachl, Lidd.

New Marunouchl Bld.

Maranouchil

1-Chome Chiyodaku

'Iokyo

JAPAN

Masakazu Fujimoto

Ebara Corporation

4-2-1 Honfujisawa

Fujlsawa-Sht

Kanagawa 251

JAPAN

Tadaaki Gocho, General Manager

Seiko Epson Corp.

1.17.1 Tsukahara

Chino-shl

Nagano, 391

JAPAN

Hiroakl Hata, Sr. Englneer Compressor Design Dept.

Hitachi Tischigi Works

800 'tomita

Ohira-machl, Shimotsuga-gun

'Jochigi 329-44

JAPAN

Katsumi Inamura

Sec. Man., AC Plant Department

Testhiba Co.

1-1-1 Shibawura, Minato-Ku

'Tokyo 105-(01

JAPAN

Nobuco Ishikawa, l'hD

Professor Emeritus of 'Rokyo Inst. of 'Tech.

Tokyo Instifute of Technology

F\&E Research Center

2-9.3 Akissika, Minalo-Ku

Tokyo 107

JAPAN
Nobuhisa lto

Matsushita Elec. Ind, Co,

2275-3 Noji.Cho

Kusntsu-Shil

Shiga 52.5

IAPAN

Atsuo Kishi, Chlel lingineer

Illtachil

2520 Oaza-14kaba, Katsuta-Shil

Ibaragi-Ken 312

JAPAN

Shunll Konatsu

Sanden Co., Lid

Yatoshima-Cho, lsezaki-Shi

Gunnma 372

IAPAN

Thkeo Konatsubara

Principal Englneer

Sanyo Electric Co., L.ed.

180 Sakali,

Oizumi-muochi, Ori-gun

Gumnaa 370-05

JAPAN

Shigeki Komalsuzaki

Senior Researcher

Hitachi Research I.atb, Hilachi Lid.

4026 Kujl-Cho Hitachi-Shi

Ibaraki 319.12

JAPAN

Kantsumi Matsubara, Deph. Manager Gith Dept.

Hitachi, Ledd.

502 Kandntsurnachi

'Tsuchilurasbi

Ibaraki-ken 300

JAP'AN

Dr. Yuji Yoshida, Manager

Luving Environmental

Systems Research Lab

3.15 Yagumo Nakanachi

Morigushi

Osakia 570

JAPAN

Kenji Matsuki, (ieneral Manager Energy Conversion Lath.

Sharp Corp.

Shinjo-Cho 282. 1 Hajikami

Kitakatsuragi-(iun

Nara 6.39-21

JAPAN 
Masalilro Noguchi

Daikin Industries, L.tld.

1.1 Nishi.Hitotsuya, Seltsu-Shi

Osuka 566

JAPAN

Yoshiyukl Mortkinwa, Manager Public Rectations of Technology

Alr.Condltioner Divlsion

Alr-Conditloner Sector

Matsushilta Elece. Ind. Co

2275-3 Noll-Cho, Kusatsu

Shiga-Ken 525

JAPAN

Hisuo Nunokawa

Calsonlc Corp.

7.3 Suknc-cho. Suno-shi

'Lochigi 327

JAPAN

Yasuhiro Onishi

Shin Meiwa Ind. Co., Lid.

6-104 Tujlkano-cho, Nishlnomiya

Hyogo 663

JAPAN

Hidetoshi Sugawa

Japan Refrig/Air Industry

3-5.8 Shibakoen, Minuto-Ku

'lokyo 105

JAPAN

Llisao Sagara

Sanyo Electric Co., Lid.

180 Sakata (otzumi-Cho

Oura-Cium

Cumma 370.05

JAPAN

Kuzuo Sihara, Mannger

Co-ordinate Sec

Air-Conditioning, Manufacturing Div.

Daikin Industries, Inc.

1304 Kanaoka-Cho, Sakai-Shi

Osaka 591

JAPAN

Kousuke Shimamura

Mitsubishi Elec. Corp.

3-18-1 Oshikia

shizuotia +22

IAPAN

Sciji Sumikiswa, Dept. Mgr.

Design Engineering Department 1

Zexel Corp.

Konn-machi, Osano-gun

Sailiama $3(0)-0)$

IAPAN
Masataka Suzukl

Mitsublshl Elec. Corp.

2-2,-3 Murnnouchl

Chlyouda.ku

'Iokyo) 100

JAPAN

Kenichl 'lluguchl

Daikin Industries, Lid.

1304 Kintaoka-cho, Sakial-sh

Osaka 591

JAPAN

Yoshikazu Thkamatsı

Calsunic Corp.

Sakile-Cho 8, Sano-Shi

'Iochigl 327

JAP'AN

Kazuml Isukahara

AC/Refrigerntion Works

Mitsubishi Henvy Industiy, Lid

3-1 Asahimachi,

Nishibiwajinia "Cho,

Nishikasugal-Gun

Adchi-Ken $\$ 52$

JAPAN

Shigehiro Uemura

Mechanlcal Engineering Lab

Chief Researcher

Daikin Ind., Lidd.

1304 Kanaoka-cho, Sakal

Osaka 591

JAPAN

Minoru Wadla, Maniger

Design Department

Fukusima Industries Co.

2-13.16, Milcjima

Nisiyodogawa-Ku

Osaka 555

IAPAN

Koichi Watanalre, PhD, Professor

Department of Mechanical Eng.

Faculty of Science and Techenology

Kelo University

3-14-1, Hyoshi, Kohokuku

Yokohama 223

JAPAN

Nobohiko Yokota, Director

Engineering Department

Japan Refrigeration \& AC: Ind. Ass.

Kikal Shinko, Bldg. 201

3-5.8, Shibakoen, Minalo-ku

Tiskyo 10.5

JAPAN
Choiku Yoshiksurn

Mayckawa Mig, Co, l.ed.

Okulxo, Nza,

Morlyin-machi, Klal-somill-gun

Ibaral: 302.0)

IAPAIY

Musaharu Youllikawa

Sharp Corp.

282.1 Hajkami, Shinje-(ho)

Nara, 630.21

JAPAN

\section{KLNYA}

James E. Kanyun, l'ho

Dept. of Mechantiscal Enginecting

University of Nairubi

B.O. Box.30197

Nalrobi

KIINYA

\section{KORLA:}

Youm Yong lee

Principal livesligator

CFC Altermatives Technical Center

Korea Inst. Science de lechnolesy

130-650 P?(). Box 131

Cheongryang

Secoul

KOREA

\section{MEXICO:}

Rene: Allimitinos

Direceion Cieneral de la Prevencion

y Contros de la Contaminacion Ambiental

Subsecretaria de licologla

SEDUE

Rio bilba No. 20) Piso 10

Colonia Cuambemoc

06500 Mexico D.I:

MIEXICO

Jorge Corona de la Vega

Astral Internaciomal

Col. Poposta

DI: 11410

MH:XICO

Geno Nardini, Marketing 1 Direconr NAYASA

Calzada Collongo, \#27a

Col. Insustriml Kallejo, BS

02300

MI:XIC) 
Valvulus Do Precislon, SA

Azulran 313

Col. Granjas Mexico

Del. Eatacialco

08400

MEXICO, D.E:

\section{'IHIE NEITHERLANDS:}

Lambert Kuljpers, PliD

Iransport Phonomena Research

Phillps Research Labs

P.O. Box 80

Eindhoven 5600 is

THE NETHERLANDS

Gen Schouten

Soldering Process Engheer Soltec [3.V?

P.O. Box 143,4900 AC Oosterhout

Karolusstrat 20

THE NETHERLANDS

Paul Vermeulen

TNO Div, of Tech, for Soc.

P.O. BOx 342

Apeldoom, 7300 AH

TTHE NETHERLANDS

\section{NEW ZEALAND:}

Lindsey Roke

Fisher \& Paykel, Refrigeration Div.

78 Springs Road

Greenmount

Auckland

NEW ZEALAND

\section{NORWAY:}

Rune Aurllen

SINTEF, DIv. Refr. Eng,

Norwegian Inst. Technology

Kjolborn Vejes

7034 Trondheim

NORWAY

Per-Erling Frivik, PhD

SINTES, Dov. Refr. Eng.

Norwegian Inst. Technolcigy

Kjolborn Vejes

70.34 Trondheim

NORLWY
Hans T Haukas, Pho

Associale l'rolessor

NTH-HINTTEF kuldeteknlkk

N.7034 'trondhelm

NORWAY

Poter Neksan, Reseurch Enginect

Relrigeratlon Englneering

N'TH-Sinlel

70.34 Trondhelm

NORWAY

Per R, Samuelsem, President

Finsam Int. Lidd.

P. O. Box 3064 EL

N.0207 Oslo 2

NORWAY

Ertk Schau, Marketing Manager

Unitor Ships Service AS

Marine Refrigeration Products

\& Servicess

Mustemyr Ind. Estate

1.O. Box 600

N.1411 Kolboln

NORWAY

\section{SWEDEN:}

'Thore Berntsson, PhD, Professcr Inst, for Heat Technology

Clialmers University

41296 Gothenborg

SWEDEN

Anders Lindtorg

Firigoscandia $\mathrm{AB}$

Technical Center, Box 912 ,

$25109 \mathrm{Helsingborg}$

SWEDEN

Bjorn E. Palm, Research Assistant Royal Inst. of Technology

Dept. of Appl. T/R

Dept. Applied Thernodynamics

\& Refrigeration

S-100 44 Stcrikholm

SWEDEN

Rolf Segerstrom

Dept. MK KKIR

Electrolux Major Appl.

Luxbacken 1

105 4.5 Stockliolin

SWEDEN
Lennart Vamillng

Chulmers Unlv, of Tlech.

Depl of lleat \& Power Ieclin.

s-412 96 Gothenburg

SWEDLEN

\section{SIVII"ZIERIAND:}

Thomas H. Christle

Refriguration Consultant

I chemin du 'tbery

1205 Milles

Le Grand-Saconnex 1218

SWI'TZERLAND

Poter Moser, Manager

Refrigeration 'Eechmolugy

Sulzer Bros. L.ld.

UBS Sulzer InIrn, Refr. lechn.

CH.8401 Winterthur

SWIT'ZERLANI)

Maturice Perenowd

Dupont Internatlonil

2 Chemin Du Pavillon

1218 Gand-Saconnex

SWITZEERLAND

\section{TAIWAN:}

Mingda Chu

Formosa Plastics Corp.

100 Swic-Kuan Rd.

Jen-Wu

Kaolisiung

TAIWAN

Trong. Deng Young

Plastics Division

Formosa Plasilics Corp

100 Swel-Kuan Rd.

Jern.wu

Kunohiung Hsien

TAIWAN

\section{UNITED KINGIOOM:}

Russell Benstead

Iechnology (iroup) Leader

Blectricily Research and

Development Centre

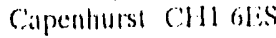

IEN(IIANI), UIK. 
Peter Couper

Salnbury's l'ke, stumbord Housc

Stumford stred

l.onklon ST:1 Q1.L

INOLAND, U.K.

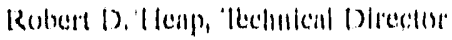
SIRC.RA

140 Nowmurket Robind

Cumbridge CBS 8118:

UNCH.AND, U.K.

Davld Hey

ICl Chemicals \& Polymers l.Ad.

P.O. Box 19

Runcorn

C.Meshire WA7 \#LW

I:NGI ANO, U.K.

Denvil Hutler, Higher Sclence Ofliker Building Research Estab)|shmen! (intston, Walford

Herts IVI)2 7.Jk

IENCII.AND, U.K

Petor Johnson, Product Manager Solvents Marketing Department ICl Chemicass and Polymers L.ts. B.O. Box 19

Runcorn

Cheshire WA7 aLW

IENCIIAND, U.K.
Itronce Jones

SEA Combalners

20) Upper (Ground

tomilon SE:Q gl't

LEN(HLAND), U.K

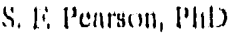

'flechnical Director

Star Rofrigoration l.del.

Thoornliebank lindustrial listate:

Glusgow $0406 \mathrm{JW}$

SCO'TLAANI), U.K.

Richurd Powall

ICI Chems, \& Polymery L.ld.

P.O. Box 8, the Heull

Runcorn

Clleshle WA7 4OD

liNCil.AND, U.K

Peter Rathibone

ICI Chein. \& Polymets litd.

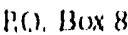

RuItcoril

Cheshire WA7 4QD)

ENGILAND, U.K

J.T.R, Wilson

National bingineering Laboratory

Heat Thansfer and Properties of

Hitulds Division

East Kollbride

Glasgow (775 OOU

SCO'ILANID, U.K.
Filonin Weir

Alr Pollutlon Campungmer

liriends of llic lanth

20.28 Underwoods simed

Lomidon Nit/.J()

IINCILAND, (I.K.

Geofley Weomes

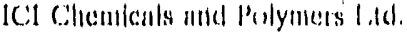
P.O. 130x 19

Runeorn

Cheshle WA7 4l.W

ENOH.AND, U.K.

A. Wilson

L.toyds Reglster of Shipplng

l.toyds Reghlster llouse:

29) Wollesiley Rrand

Croydon CRO $2 \mathrm{Al}$

I:N(H.ANI), IJK.

Neil Wintertont

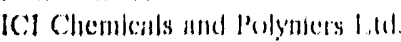
BOO. $B 0 \times 19$

Runcorn

Clesthire WVA7 HWW

IUNCII.AND), II,K 


\section{DISTRIBUTION}

No. of

Coptes

\section{OFFSITE}

12 DGE/Office of Sctentific and Technical Information

L. R. Anderson

CE-422

U.S. Department of Energy 1000 Independence Avenue SW Washington, DC 20585

D. B. Bivens

Dupont Company

Rt. 130 Canal Road

Trailer K-37

Deepwater, NY 08023

R. Bradley

S-1

U.S. Department of Enery.y 1000 Independence Avenue SW Washington, DC 20585

F. A. Creswick

Martin Marietta Energy Systems Oak Ridge National Laboratory Energy Division

$X-10$ Plant, Building 3147

Oak Ridge, TN 37831-6070

J. J. Cuttica

Gas Research Institute 8600 W. Bryn Mar Avenue

Sutte 1100

Chicago, IL 60631

K. D. Devine

CE- 44

U.S. Department of Energy 1000 Independence Avenue SW Washington, DC 20585
No. of

Coptes

J. J. Eberhardt

CE-34

U.S. Department of Energy

1000 Independence Avenue SW Washington, DC 20585

P. D. Fatrchild

Martin Marfetta Energy Systems Oak Ridge National Laboratory Energy Division $X-10$ Plant, Butlding 3147

Oak Ridge, TN 37831-6076

A. P. Fickett

EPRI

3412 Hillview Ave.

Palo Alto, CA 94304

S. E. Fischer

Martin Marietta Energy Systems Oak Ridge National Laboratory Engineering Technology

Y-12 Plant, Buildting 1104-1

Oak Ridge, TN 37831-8057

K. M. Friedman

CE-20

U.S. Department of Energy

1000 Independence Avenue SW

Washington, DC 20585

M. Ginsberg

CE-44

U.S. Department of Energy 1000 Independence Avenue SW Washington, DC 20585

P. A. Joyner

EPRI

3412 Hillview Ave.

Palo Alto, CA 94304 
No. of

Coptes

T. E. Kapus

$C E-42$

U.S. Department of Energy 1000 Independence Avenue SW Washington, DC 20585

E. R. Kweller

CE-422

U.S. Department of Energy 1000 Independence Avenue SW Washington, DC 20585

J. P. Lupinachi

U.S. EPA Headquarters, ANR 445 401 M. Street SW, Room M-3202 Washington, DC 20460

M. McFarland

Dupunt Company

1007 Market Street

B $\$ 13230$

Willmington, DE 19898

M. S. Mesnzer

VP Research and Technology APRI

1501 Wilson Belivard Sixth 11 . Arlington, VA 22209-2403

J. P. Mithone

CE-40

U.S. Department of Energy 1000 Independence Avenue SW Washington, DC 20585

J. D. Ryan

CE -422

U.S. Department of Energy 1000 Independence Avenue SW Washington, DC 20585

T. Statt

CE -422

U.S. Department of Energy 1000 Independence Avenue SW Washington, DC 20585
No. of

Coptes

K. Ushimaru

Energy International, Inc.

301 - 116th Ave. S.E.

Suite 200

Bellevue, WA 98004

D. K. Walter

CE-222

U.S. Department of Energy 1000 Independence Avenue SW Washtngton, DC 20585

E. R. Willitams

PE-70

U. S. Department of Energy $1000^{\prime}$ Independence Avenue Sw Washington, DC 20585

\section{FOREIGN}

Chris Baker

Manager, Ozone Unit

EPA

477 Collins

Melbourne, Victoria

3000 AUSTRALIA

Robert L. Muston

Environmental Products

Amalgamated Pty. Ltd

5-25 Calaster Street.

P.0. Box 191

Shepparton, Victoria

AUSTRALIA

M. Narodos 1 awsky, PhD Institute of Chemical

Engineering

Graz University of Technology

8010 Graz

AUSTRIA

M. Schneeberger

Vorst. Oberoesterrische

Kraftwerke AG, OKA

Boehmerwaldstrasse 3

4020 Linz

AUSTRIA 
No. of

Copies

Alberto Carrizo

Climax Industries

Av. Jose Peretra Lopes 250

13560 Sao Carlos

BRAZIL

Ernesto Heinzelmann

Embraco SA

Rua Rui Barbosa, 1020

892.00 Joinville

BRAZIL

Pauto Vietra

Dupont

A1 Itapecuru 506-Alfazil

Cepo 6400 CP 26

BRAZIL

Paulo Vodianitskaia

Systems Engineering

Consul SA

Caixa Pustal 267/269, CEP89200

892.00 Joinvtlle

BRAZIL

Michael R. Ascough

Du Pont Canada

Box 2200, Streetsvil1e

Mississauga,

Ontario L5M2H3

CANADA

Stephen Griffin

W. C. Wood Co., Ltd.

P.0. Box 750

5 Arthur Street S.

Guelph N1H 6L9

CANADA

Paul A. LaRue

CRIQ

Post Office Box 9038

Ste-Foy, Quebec G1V 4C7

CANADA
No. of

Coptes

Jeffrey Linton

Nat1. Res. Counc 1l Canada

Bldg. M17, Montreal Rd.

Ottawa, Ontarto KIAORG

CANADA

Keith Snelson

Nat 1. Res. Counc 11. Canada

Bldg. M17, Montreal Rd.

Ottawa, Ontarto KIA ORG

CANADA

Art Stelzig

Environment Canada

351 St. Joseph B1vd.

Huly Quebec, Ontario K2H5Ng

CANADA

Yu Bing Feng, PhD

Assistant Professor

AC Group, Department Power Mach

$\mathrm{Z}^{\prime}$ 'an Jiaotong Untversity

$X_{i}^{\prime}$ an (Shaanxi)

CHINA

Ren Jinlu

Refrigeration Group

General Mach. Research

Institute GMRI

Shushan Road, P.0. 230031

Hefei

CHINA

H. C. Aagaard

Danish Technological Institute

Gregersenszej, P.0. Box 141

Taastrup, DK

2630 DENMARK

Per 0. Danig

Refrigeration Laboratory

Technical University,

Bldg. 402B

2800 Lyngby

DENMARK 
No. of

Copies

\section{Asger Gramkow \\ A'Gramkow \\ Augustenborg Landezej 19 \\ Sonderborg, DK \\ DENMARK 6400 \\ Erik Korfitsen \\ Development Department \\ Industry Division \\ Sabroe Refrigeration $A / A$ \\ P.0. Box 1810 \\ 8270 Hojbjerg \\ DENMARK}

C. Brian

Dehon Service

26 Ave. dupetit Parc

Vincennes 94683

FRANCE

Denis Clodic

Armines

60 , Bd St. Miche1

75272

Paris 75006

FRANCE

Brian Ellis

Protonique

P.0. Box 78

Romanel-Sur-Luasanne $\mathrm{CH}-1032$

FRANCE

H. D. Baehr, PhD, hc

Institute of Thermodynamics

University of Hannover

Callinstrasse 36

3000 Hannover 1

GERMANY

Ingrid Hanhoff-Stemping

Umwektbundesamt

Bismark Platz 1

1 Berl in 33

GERMANY
No. of

Copies

P. E. Hansen, PhD

Danfoss GinbH

Reliability and Labs

Mads Clausenstrasse 7

2390 Flensburg

GERMANY

UTrich Hesse

University of Hannover

Wel Fen Garten $1 \mathrm{~A}$

Hannover, FR 3000

GERMANY

Warner Jensen

Leberstrasse 3

2390 Flensburg

GERMANY

Michael Kauffeld

University of Hannover

Isti. fur kaltetech

Welfangarten $1 \mathrm{~A}$

D-3000 Hannover 1,

GERMANY

Michael Kauffeld

University of Hannover

Isti. fur kaltetech

Welfangarten $1 \mathrm{~A}$

D-3000 Hannover 1,

GERMANY

Horst Kruse, PhD

Inst. Kaeltetechnik

University of Hannover

3000 Hannover 1

GERMANY

Gunter Langer

Battelle Europe

Am Romerhof 35

6000 Frankfurt - Main 90

Frankfurt

GERMANY 
No. of

Copies

Klaus W. Menze

Wieland-Werke $A G$

Post Office Box 4240

UTm, D-7900

GERMANY

J. F. Nonenmacher, PhD

Sudd Kuehlerfabr Behr GmbH

Mauserstrasse 3

7000 Stuttgart 30

GERMANY

Rolf Wallner, PhD

Dept. Head Predevelopment

Sudd Kuehlerfabr Behr GmbH

Mauserstrasse 3

7000 Stuttgart 30

GERMANY

Russe 11 Benstead

Electricity Research and Development Centre

Capenhurst $\mathrm{CH} 1$ 6ES

England

UNITED KINGDOM

Peter Cooper
Sainbury's Place
Wakefield House
Stanford Street
London SEI 9EL
England
UNITED KINGDOM
Robert Heap
SRCRA
140 Newmarket Road
Cambridge .CB5 8 HE
England
UNITED KINGDOM
David But Ter
Higher SCience Officer
Bldg. Research Establishment
Garston, Watford
Herts WD27JR
England
INITED KINGDOM

No. of

Copies

S. F. Pearson, PhD

Star Refrigeration Ltd.

Thornlie Bank, Ind. Estate

Glasgow G46 8JW

Scotiand

UNITED KINGDOM

\section{Richard Powe 11}

ICI Chems. \& Polymers Ltd.

P.0. Box 8, The Heath

Runcorn, Cheshire WA7 4QD

England

UNITED KINGDOM

Dr. James T.R. Watson

National Engineering Laboratory

Heat Transfer and Properties of Fluids Division

East Kilbride

Glasgow GT5 OQU

Scotiand

UNITED KINGDOM

Fiona Weir

Friends of the Earth

26-28 Underwood Street

London N17JQ

England

UNITED KINGDOM

A. Wilson

Lloyds Register of Shipping

Lloyds Register House

29 Wellesley Road

Croydon CRO 2AJ

England

UNITED KINGDOM

R. S. Agarwal, PhD

Department of Mechanical Engineering

Indian Institute of Technology

Hauz-Khas

New Delhi 110016

INDIA 
No. of

Copies

S. C. Bhaduri, PhD

Institute of Mechanical

Engineering

Indian Institute of Technology

Powai

Bombay $400 \quad 076$

INDIA

Sukumar Devotta, PhD

Assistant Director

Chemical Engineering Division

National Chemical Laboratory

Pune 411008

INDIA

Gianfranco Angelino, PhD

Energy Department

Politecnico di Milano

Piazza Leonardo da Vinci, 32

20133 Milano

ITALY

Tadatoshi Banse

Manager, Engineering

Department 60335

Toshiba Co., Comsumer Products

1-1-1 Shibaura, Minato-Ku

105-01 Tokyo

JAPAN

Yoshiyuki Ishii

Hitachi, Ltd.

New Marunouchi Bid.

Marunouchi

I-Chome Chiyodaku

Tokyo

JAPAN

Tadaaki Gocho

Seiko Epson Corp.

1-17-1 Tsukahara

Chino-shi, Nagano 391

JAPAN
No. of

Copies

Hiroaki Hata

Nitachi, Ltd.

800 Tomita

Ohira-machi

Shimotsuka-gun, Tochi 329-44

JAPAN

Nobuo Ishikawa, PhD

Tokyo Institute of Technology

Director, F\&T Research Center

2-9-3 Akaska, Minato-Ku

Tokyo 107

JAPAN

Atsuo Kishi

Hitachi

2520 Oaza-Takaba Katsuta-Shi

Ibaraki-Ken 312

JAPAN

Takeo Komatsubara

Sanyo Electric Co., Ltd.

180 Sakata,

0izumi-machi

Ora-gun, Gumma 370-05

JAPAN

Shifeki Komatusuzaki

Hitachi

4026 Kuji-Cao Hitachi-Shi

Ibaraki-Ken 319-12

JAPAN

Katsumi Matsubara

Hitachi, Ltd.

502 Kandatsu-cho

Tsuchiura, Ibaraki 300

JAPAN

Tooru Matsui

Matsushita Elec. Inc. Co.

Electrochem. Mat1s.

Research Lab.

Moriguchi, Osaka 570

JAPAN 
No. of

Copies

Kenji Matsuki

Man. Energy Conversion Lab.

Engineering Center

Sharp Co., 282-1 Hajikami, Shinjo-Cho, Kitakatsuragi-Gum

Nara 639-21

JAPAN

Masahiro Moguchi

Daikin Industries, Ltd.

1-1 Nishi-Tsuya

Settsu-Shi

Osaka 566

JAPAN

Yoshiyuki Morikawa

Matsushita Elec. Ind. Co

2275-3 Noji-Cho

Kusatsu-Shi

Shiga 525

JAPAN

Hisao Nunokawa

Calsonic Corp.

7-3 Sakae-cho

Sano-shi, Tochigi 327

JAPAN

Hisao Sagara

Sanyo Electric Co., Ltd. 180 Sakata Oizumi-Cho

Ora-Gun

Gumma 370-05

JAPAN

Kazuo Sahara

Daikin Industries, Inc.

1304 Kanaoka-Cho

Sakai-Shi

Osaka 591

JAPAN
No. of

Copies

Seiji Sumikawa

Man. Comp. Engineering Department

Deisel Kiki Ltd., Co.

39, Sendai, Konon-machi

Osato-gun

Saimata-Ken 360-01

JAPAN

Kazumi Tsukuhara

AC/Refrigeration Works

Mitsubihi Heavy Industry

3-1 Asahimachi,

Mishibiwajima-Cho,

Nishikasuga i-Gun

Aichi-Ken 452

JAPAN

Shigehiro Uemura

Daikin Ind., Lt.d.

1304 Kanaoka-cho

Sakai-shi, Osaka 591

JAPAN

Koichi Watanabe, PhD

Professor

Department of Mechanical

Engineering

Faculty of Science and Technology

Keio University

3-14-1, Hiyoshi, Kohok-Ku

Yokohama '223

JAPAN

Nobohiko Yokota

Director Engineering

Department

Japan Refrigeration \& $A C$ Ind. Ass.

Kikai Shinko, Bldg. 201

3-5-8, Shibakoen, Minato-Ku

Tokyo 105

JAPAN 
No. of

Copies

Masaharu Yoshikawa

Sharp Corp.

282-1 Hajikami

Shinjo-Cho

Nara 639-21

JAPAN

James F. Kanyua, PhD

Department of Mechanical

Engineering

University of Nairobi

P.0. Box 30197

Nairobi

KENYA

Youn Yong Lee
Director
CFC Alternatives Technical
Center
Korea Inst. Science \&
Technology
$130-650$ P.0. Box 131
Cheongryang, Seoul
KOREA

Rene Altimirano

Direccion General de la Prevencion y Control de 1 a Contaminacion Ambiental

Subsecretaria de Ecologia SEDUE

Rio Elba No. 20 Piso 16,

Colonia Cuauthemoc

06500 Mexico D.F.

MEXICO

Geno Nardini

NAYASA

Calzada Coltongo, \#272

Col. Industrial Zallejo, BS

02300

MEXICO

Lambert Kuijpers, PhD

Transport. Phonomena Research

Phil ips Research Labs

Eindhoven $5600 \mathrm{JA}$

NETHERLANDS
No. of

Copies

Paul Vermeulen

TNO Div. of Tech. for Soc.

P.0. Box 342

Apeldoorn, $7300 \mathrm{AH}$

NETHERLANDS

Gert Schouten

Soltec Manufacturing

P.0. Box 143, 4900 AC 0oster Hout

Karolusstraat 20

NETHERLANDS

Lindsey Roke

Fisher \& Paykel, Refrigeration Division

78 Springs Road

Greenmount, Auck 1 and

NEW ZEALAND

Hans Haukas, PhD

Refrigeration Inst.

NTH University

Kjolborn Vejes

7034 Trondheim

NORWAY

Peter Neksaa

Sintef/NTH Div. of Refrig.

Eng.

N-7034 Trondheim

NORWAY

Per Samuelsen

Finsam Int. Ltd.

P.0. Box 3065 EI

Os7o 0207

NORWAY

Erik Schau

Unitor Ships Service

P.0. Box 600

Kolbotn 1411

NORWAY 
No. of

Copies

Thore Berntsson, PhD

Inst. for Heat Technology

Chalmers University

41296 Gothenborg

SWEDEN

Anders Lindborg

Frigoscandia $A B$

Technical Center, Box $91^{9}$

25109 Helsingborg

SWEDEN

Bjorn E. Palm

Royal Inst. of Technology

Dept. of App 1. T/R

Stockholm, S-1.00 44

SWEDEN

Lennart Vamling

Chalmers Univ. of Tech.

Dept. of Heat/Power

Gothenburg, S-412 96

SWEDEN

Thomas H. Christie

DuPont De Nemours Inter.

Post Office Box 50

2, Chemin Du Paviln.

Le Grand-Saconnex, 1218

SWITZERLAND

Peter Moser

Sulzer Bros. Ltd.

UB Sulzer Infra, Refr. Techn.

8401 Winterthur

SWITZERLAND

Tzong-Deng Young

Plastics Division

Formosa Plastics Corp

100 , Swei-Kuan Rd.

Jen-wu Kaohsiung Hsien

TAIWAN

\section{ONSITE}

DOE Richland Field office

D. R. Segna

23 Pacific Northwest Laboratory

W. B. Ashton (5)

R. S. Butner

L. D. Kannberg

T. J. Marseille

S. C. McDonald

D. L. Shankle (5)

A. G. Thurman

S. A. Weakley

J. K. Young

Publishing Coordination

Technical Report Files (5)

Distr.9 

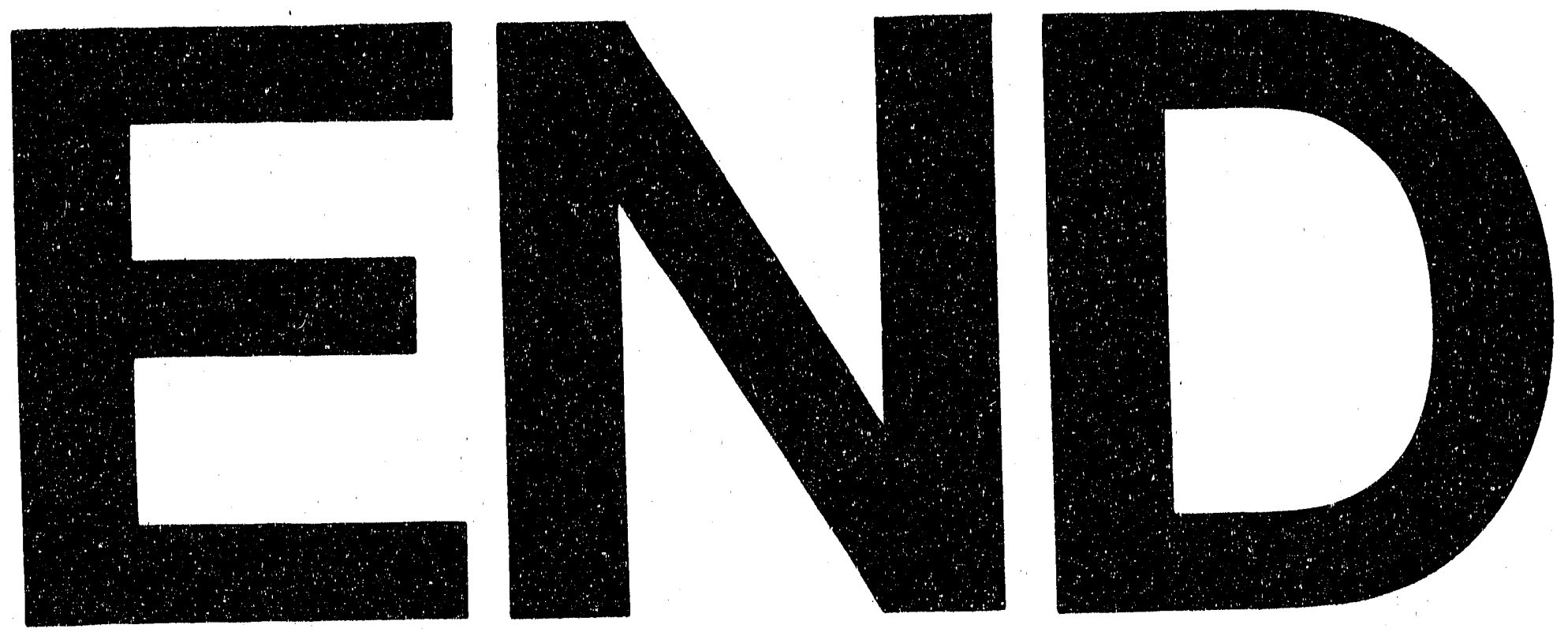

$\overline{\bar{E}}$
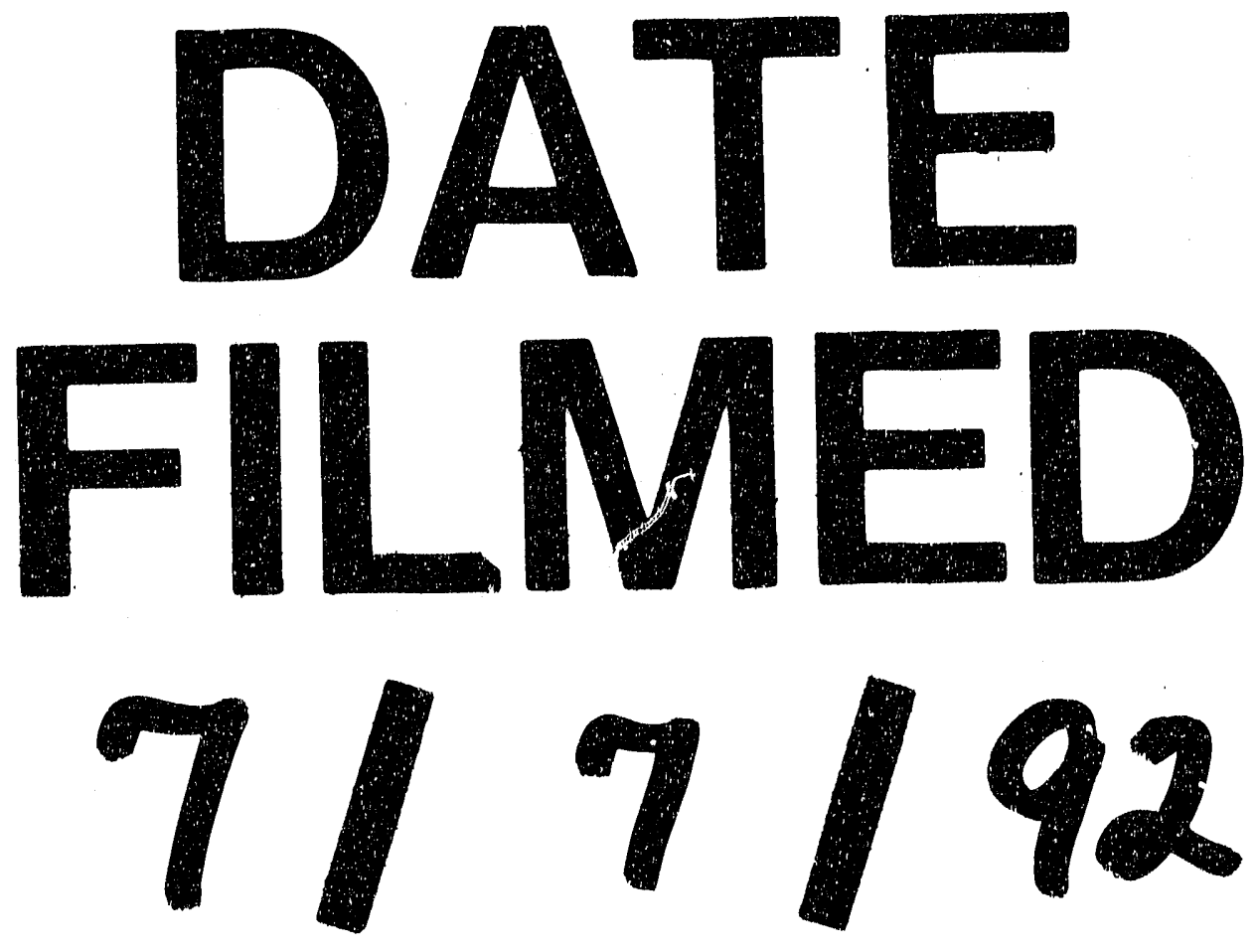

覀 
